Utah State University

DigitalCommons@USU

$5-1969$

\title{
A Comparison of the Drinking Behavior of Delinquent Youth Versus Non-Delinquent Youth in the States of Idaho and Utah
}

Henry Dean Garrett

Utah State University

Follow this and additional works at: https://digitalcommons.usu.edu/etd

Part of the Education Commons, and the Medicine and Health Sciences Commons

\section{Recommended Citation}

Garrett, Henry Dean, "A Comparison of the Drinking Behavior of Delinquent Youth Versus Non-Delinquent Youth in the States of Idaho and Utah" (1969). All Graduate Theses and Dissertations. 2932.

https://digitalcommons.usu.edu/etd/2932

This Thesis is brought to you for free and open access by the Graduate Studies at DigitalCommons@USU. It has been accepted for inclusion in All Graduate Theses and Dissertations by an authorized administrator of DigitalCommons@USU. For more information, please contact digitalcommons@usu.edu.

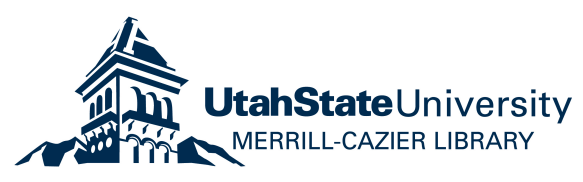


A COMPARISON OF THE DRINKING BEHAVIOR OF DELINQUENT YOUTH VERSUS NON-DELINQUENT YOUTH IN THE STATES OF IDAHO AND UTAH

by

Henry Dean Garrett

A thesis submitted in partial fulfillment of the requirements for the degree

of

MASTER OF SCIENCE

in

Health Education

UTAH STATE UNIVERSITY

Logan, Utah

1969 


\section{ACKNOWLEDGMENTS}

Sincere appreciation is expressed to Miss Janice Pearce, chairman of my graduate committee, for her help and encouragement in carrying out my research and in writing this thesis. Appreciation is also expressed to Dr. W. Whitney Smith and Miss Pauline Fuller, members of my committee, for their suggestions and assistance in completing my research and for their critical review of my thesis.

I would also like to thank the following for their assistance and cooperation in administering my questionnaire:

Mr. Claud H. Pratt, superintendant, and Mr. Don Tatton, assistant superintendant, Utah State Industrial School, Ogden, Utah.

Mr. Winston G. Taylor, superintendant, Youth Training Center, St. Anthony, Idaho.

Mr. Thomas A. Strah, director of secondary education, Pocatello School District, Pocatello, Idaho.

Mr. Robert Gouch, Pocatello Senior High School.

Mr. Robert Gould, Highland Senior High School.

Mr. Ronald Reed, Alameda Junior High School.

Mr. Gene Soderquist, Franklin Junior High School.

Appreciation is extended to the students who filled out the questionnaire.

Special thanks is given to my wife, Patsy, for her patience, understanding, and time devoted to typing and editing this thesis.

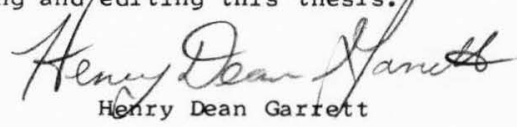




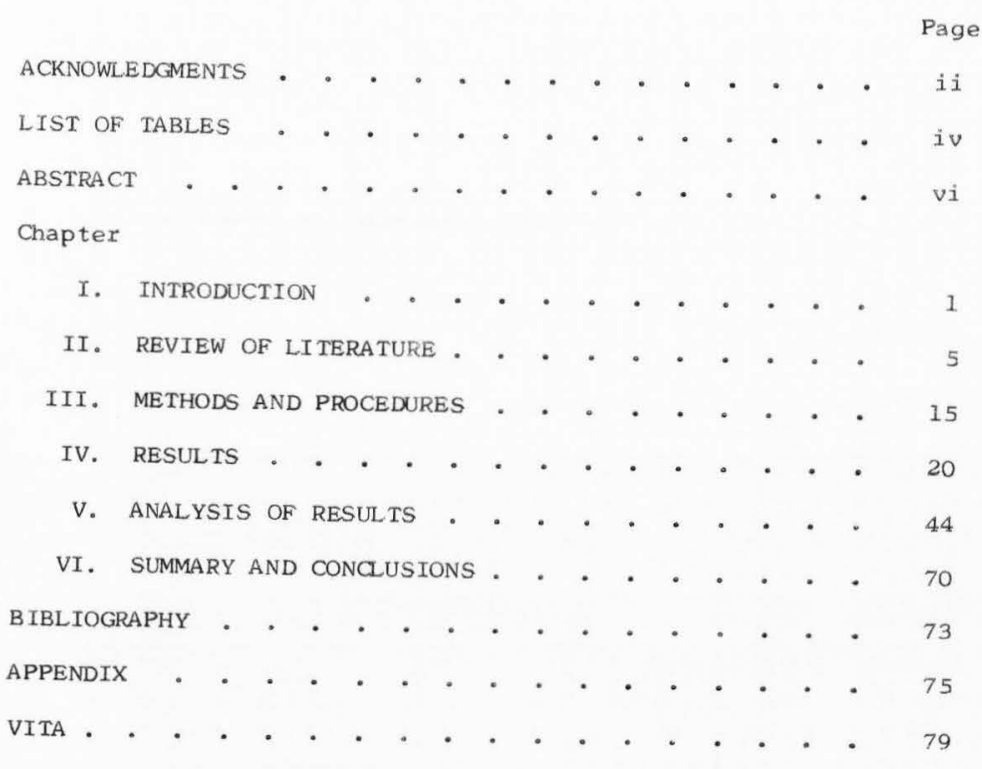




\section{LIST OF TABLES}

Table

1. Present age of selected sample of delinquents and non-delinquents . . . . . . . . . . 21

2. Descriptive background of a selected group of delinquent and non-delinquent juveniles . . . . 22

3. With whom the students lived at home . . . . 25

4. Frequency of parents' drinking . . . . . . . 26

5. Age of first drink . . . . . . . . . 28

6. Factors concerning first drink of delinquents and non-delinquents . . . . . . . . . 30

7. Present drinking behavior of delinquents and non-delinquent

8. Influence of alcohol on behavior of delinquents and non-delinquents . . . . . . . .

9. Opinions of delinquents and non-delinquents on questions concerning the drinking of alcoholic

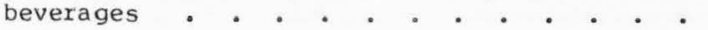

10. Frequency of drinking compared with present age of delinquents

11. Frequency of drinking compared with present age of non-delinquents

12. Frequency of drinking compared with sex . . . . 52

13. Frequency of delinquent's drinking compared with race

14. Frequency of non-delinquent's drinking compared with race

15. Frequency of drinking compared with family income . 57

16. Frequency of drinking compared with area lived in . 59

17. Frequency of drinking compared with whom the students lived. 


\section{LIST OF TABLES (continued)}

Table

Page

18. Frequency of delinquent's drinking compared with father's drinking behavior . . . . . . .

19. Frequency of non-delinquent's drinking compared with father's drinking behavior . . . . . . 64

20. Frequency of delinquent's drinking compared with mother's drinking behavior. . . . . . 66

21. Frequency of non-delinquent's drinking compared with mother's drinking behavior . . . . . . 67

22. Frequency of delinquent's drinking compared with attitude toward drinking. . . . . . . 68

23. Frequency of non-delinquent's drinking compared with attitude toward drinking . . . . . . . 


\section{ABSTRACT}

A Comparison of the Drinking Behavior of Delinquent

Youth versus Non-delinquent Youth in the

$$
\text { States of Idaho and Utah }
$$

by

Henry Dean Garrett, Master of Science

Major Professor: Janice Pearce

Department: Health Education

A questionnaire on drinking behavior and attitudes was administered to 292 delinquent youth confined in youth detention homes in St. Anthony, Idaho, and Ogden, Utah, and to 466 students in the secondary schools of the Pocatello School District, Pocatello, Idaho.

Using a Chi Square analysis, comparisons were made of responses between the delinquent and non-delinquent groups to questions regarding first drinking experience, present drinking behavior, attitudes toward drinking, criminal acts while drinking alcoholic beverages, age, race, sex, family income, population of area lived in, with whom the students lived, and parents' drinking behavior. Significant differences at the .001 per cent level were found between the responses of delinquents and non-delinquents in all areas compared with the exception of the father's drinking behavior where a difference at the .05 per cent level was found.

In summary, the results showed that the delinquent population of this study (1) began drinking sooner and more 
frequently than the non-delinquent population, (2) drank for different reasons than the non-delinquents, and (3) drank without their parents' permission more frequently than the non-delinquents. In addition, a higher percentage of the non-delinquents did not drink in comparison with the delinquents who did.

This study also indicated that the older the delinquent and non-delinquent students were, the more frequently they drank. The frequency of drinking of both the delinquent and the non-delinquent students was related to the frequency of their parents' drinking. As the parents drank more frequently, the more frequently the delinquent and non-delinquent students drank. 


\section{CHAPTER I}

\section{INTRODUCT ION}

\section{Origin and nature of problem}

The drinking of alcoholic beverages has become an acceptable social custom in this society. Mulford, in a 1963 national study, found that 71 per cent of Americans 21 years of age or over drank alcoholic beverages (15, p. 1). However, not only do adults drink alcoholic beverages, but teenagers also drink alcoholic beverages. Maddox estimated that the probability is high that every adolescent in our society will have used an alcoholic beverage at least once before graduating from high school (10, p. 35).

What are the drinking behavior and drinking habits of the youth today? How extensive is the use of alcohol? Is there a difference existing between the drinking habits of delinquent youth and non-delinquent youth? Are alcoholic beverages a contributing factor to juvenile delinquency?

Relatively little research has been done, or at least published, in the area of the drinking behavior of delinquent and non-delinquent youth. The purpose of this study was to examine the drinking behavior of adolescents in the states of Idaho and Utah--specifically, to make a comparison of the drinking behavior of delinquent versus non-delinquent youth. Uncertainty seems to exist as to what the drinking behavior 
of youth is, and whether a significant difference exists between the drinking habits of delinquent and non-delinquent youth. There is also uncertainty as to whether the drinking of alcoholic beverages is a contributing factor to juvenile delinquency.

\section{Objectives}

Specifically the objectives of this study were:

1. To determine the drinking behavior of delinquent youth and non-delinquent youth.

2. To determine if there is a significant difference in the drinking behavior of delinquent youth and nondelinquent youth.

3. To determine if there is a significant relationship between the drinking habits of delinquent juveniles and their delinquent acts.

4. To investigate the relationship of selected socioeconomic factors to the drinking behavior of delinquent and non-delinquent youth.

\section{Limitations}

1. This study will deal only with junior and senior high school students in the Pocatello, Idaho, School District, as the non-delinquent sample. The youth confined in detention homes in St. Anthony, Idaho, and Ogden, Utah, were the delinquent sample. It is realized that some students attending public high schools could be classified as delinquents. 
2. There is a possibility of confusion by the students in defining what was meant by a "drink" of an alcoholic beverage.

3. This study did not take into consideration the use of wine in the home and church in connection with religious ceremonies and services.

4. This study is valid only in relation to the degree of honesty with which the students responded to the questionnaire. There is a realization that, due to the number of times some of the delinquents have been tested, a conditioning to such testing might have occurred whereby answers may be given which the delinquents feel the tester wants or which they consider to be the "correct" response.

5. The sample from the Pocatello secondary schools were not randomly selected, but were selected by school personnel with the belief that a cross section of each school's population was represented.

6. As a result of the program used by the computer, there is no break down of responses by sex. The responses to some questions would have been more meaningful had this information been available.

\section{Definitions}

1. Delinquent. The term delinquent for the purposes of this study will be defined as a youth being confined in a state Detention Home at the time of this study.

2. Drinking behavior or drinking habits. The terms drinking behavior and drinking habits will be used inter-changeably to mean the customary drinking practices or acts of the individual. 
3. Youth, adolescent, and juvenile. The terms youth, adolescent, and juvenile, as used in this study, would include anyone between the ages of twelve and eighteen years of age.

4. Alcoholic beverage. An alcoholic beverage is defined as any intoxicating liquor which contains ethyl alcohol, including 3.2 per cent beer. 
CHAPTER II

REVIEW OF LITERATURE

\section{$\underline{\text { Introduction }}$}

In pursuing information concerning the drinking habits of delinquents and non-delinquents, the following questions were asked: How many juveniles consume alcoholic beverages, and do any serious problems arise from this consumption? Kleiner stated, "Drinking among teen-agers today is as serious a problem as drinking along Skid Row." (6, p. 31)

In this review of literature, an attempt has been made to present the extent of the use of alcohol by juveniles and whether or not there is a relationship between the use of alcohol by juveniles and juvenile lawlessness.

Use of alcohol by juveniles

Use of alcohol by non-delinquent juveniles. In summarizing five studies made of the drinking behavior and attitudes of more than 8,000 high school students from 1948 to 1963 , Maddox noted that the probability is high that every adolescent in our society will have used an alcoholic beverage at least once before graduating from high school (10, p. 35). In another study by Maddox and McCall of 1,962 eleventh- and twelfth-grade high school students in a middle-sized, mid-western city, they found that 92 per cent of the students had been exposed to the use of alcoholic beverages, 23 per cent had established patterns of use, and 9 per cent identified themselves as drinkers (12, p. 669). McCarthy's article reported that since 1952, three 
comprehensive surveys of adolescent drinking have been conducted (13). One was conducted in Nassau County, New York, another in Racine County, Wisconsin, and a thizd in Kansas. In Nassau County, a highly urbanized area near New York City, a sample of 1,000 students was drawn from 29 public and private high schools by a group of researchers from Hofstra College. It was found that 12 per cent had never used alcohol, 2 per cent used alcoholic beverages in conjunction with a religious observation only, 22 per cent drank both socially and in connection with a religious ritual, and 64 per cent drank socially. Eighty-four per cent reported they were not total abstainers. A significant increase was found in the use of alcoholic beverages from lower age levels to higher age levels. Seventy-nine per cent of the 14 year olds were users, 82 per cent of the 17 year olds, and 89 per cent of the 18 year olds and older. The rate of use was found to be lower in Wisconsin than in Nassau County, New York; and the rate of use was lower in Kansas than in Wisconsin. The rate of use was found to vary with age, sex, parental drinking practices and attitudes, size of community, and religion.

A study was made of the use of alcoholic beverages among 1,177 high school students in Utah by Slater (17). Tenth- and twelfth-grade students were studied. An unexpected finding of this study was that a higher percentage of both boys and girls in grade ten drank than boys and girls in grade twelve. Sixtyeight per cent of the students studied reported they had never drunk, with 65 per cent of the tenth-grade students, and 70 per cent of the twelfth-grade students reporting they had never drunk alcoholic beverages. 
Another study of the use of alcohol by young people in Utah was made by Nelson (16). His sample of approximately 1,325 high school seniors was selected from nine selected high schools along the Wasatch Front from Smithfield on the north to Provo on the south. Only senior students were surveyed because it was felt that it would be at this age where the heaviest drinking would take place. He found that 66 per cent of the high school senior surveyed had drunk an alccholic bevezage, with an average age of first drinking being 14.56 ( 14.38 for boys and 15.22 for girls).

In a study of 3,388 male students attending seven junior and senior high schools in three metzopolitan Boston communities, Demone found that most male teenagers in his study drank increasingly so as they progressed through adolescence (3). By 17 more than 90 per cent reported at least one experience with alcohol; however, dxinking was seldom found to be excessive. A study of more than 2,000 junior and senior high school students from three communities in Michigan found that about one student in ten classified himself as a person who drinks (18). What reasons did the teenagers give for drinking? In the study by Maddox and McCa11, the reasons given by the teenagers studied emphasized sociability and self-expression (12). Sower believed that teenage drinking was culturally patterned, socially controlled, and almost entirely a group act (18). Demone also believed that male adolescent drinking reflected group practices (3). The majority of the students surveyedby slater gave "to follow the crowd" as their reason for drinking (17).

When did the teenagers studied take the Ir first drink? 
Maddox stated that the fusat pexsonal uae tends to occur about the thizteenth ox fourteenth yex (10, p. 35). S1ater supports this finding also (17). He found that the mean age for male teenagers was 14.4 ; and for femile teenagers, it was 14.5 years of age.

Use of alcohol by del nquent juveniles. Mckay, with the help of severial associates, made several tudies of delinquency and drinking. In one of his studies, the in'ezwewed 122 delinquent males ranging from age 8 to $9 \mathrm{ge} 17$ (8). He tried to discover the existence and the extent of problem drinking and also the boys' attitudes about the dzinking and non-drinking done by adults and by other adolescents. From this study, it was found that 16 per cent of the boys were problem drinkers. The average age of the problem drinker was six*een.

In an earlier study by Mackay and his associates, 500 male delinquents in Massachusetts were sumreyed (7). They were characterized according to drinking behavior. They were classi.. fied as being abstainers, single drinking episode, mild drinkers, moderate drinkers, heavy dzinkers, of problem drinkers. The delinquents studied ranged in ages fxom seven to twenty, with an average of fifteei years of age. Ten per cent of the 500 delinquents were classified as problen drinkezs. Thisty-eight delinquents took their first drink at age thitteen or fourteen, and curiosity seemed to be given mo:t frequently as the ceason for drinking.

Blacker et 31 . Studied 500 delinquent boys in the Youth Reception Center of the Commonwerlih of Massachusetts (1). A 
questionnaire was administered on drinking behavior, effects, attitudes toward drinking, pazental drinking behavior, and social characteristics. They found that 28 per cent of the delinquents were abstainers, 9 per cent had used alcohol once, and 63 per cent had had two or more drinking experiences. Eighty-three per cent of the delinquents over seventeen years of age and 21 per cent of the delinquents under twelve years of age were drinkers. The type of drinker correlated significantly with age and with the older boys being in what Blacker et al. defined as "relief" and "pathological" groups.

Nelson questionned approximately 130 students confined in the Utah State Industrial School in Ogden, Utah. This group represented all four grades of high school. He found that the delinquent students questionned drank more and started earlier than the high school non-delinquent students he questionned (16). Comparison of use by delinquent and non-delinquent juveniles. Few studies were found comparing the use of alcohol by delinquents and non-delinquents. In a study by MacKay et a1, information on drinking behavior was collected from institutionalized youth in New Hampshire, and from junior and senior high school students in rural, urban, smal1 towns neaz industrial complex, and small towns far removed from urban areas (9). They found that 14 per cent of the delinquents and 28.5 pez cent of the junior and senior high school non-delinquent students had not had a drink of any kind of alcoholic beverage. The average age for taking the first drink was 13 for the delinquents and 12 for the non-delinquent students. More than one-half of the 
non-delinquent students had theil first $d$ zink at home under adult supervision; but only 20 per cent of the delinquents had their first drink in the presence of aduits, and they had it without adult sanction. The results of this study also showed that fewer non-delinquents than delinquents were likely to have continued drinking after their first experience with alcohol, and more evidence of "serious" drinking behavior was detected among the delinquents than among the non-delinquent students. They also found that the delinquents drank for tension relief more frequently than did the non-delinquent students.

In comparing the findings in the three studies by Mackay and his associates (8), and the summary of the studies made by Maddox (12), MacKay believed there was a marked difference in his findings and in those outlined in the Maddox summary of the studies of "normal" juvenile drinkers. The "normal" juveniles took their first drink within the hore in the presence of their parents or other relatives. They also had a tendency to look at drinking as an adult function involving comradeship or good fellowship and celebration. They had a tendency to drink in terms of what alcohol does "for" rathez than "to" a person. This is in sharp contrast to the delinquent boys Mackay and his associates studied who drank "to get high or tight." The delinquent boys' first drinking experiences were radically different from those of the "normal" juveniles. The delinquent boys had their fixst drink away from home and away from adult superivision. In most cases, their first drink was taken before they reached 13 years of age. 
The problem of juvenile lawiessness

In trying to determine the extent of juvenile lawlessness, statistics show that theze has been an increase in juvenile delinquency over the past few years. Therefore, juvenile lawlessness does seem to be increasing. However, there is a problem in the interpretation and in the reliability of the statistics because of the gathering procedures used, changes in state and local laws, and the varying definitions of juvenile delinquency. Therefore, one must be careful in the use of statistics regarding juvenile lawiessness.

The relationship of alcohol to juvenile lawlessness. Jackson wrote regarding juvenile lawlessness:

As yet there is no one accepted theory of the cause of criminal behavior. As a result, the literature presents a confusing picture of the relationships between alcohol and crime. (5, p. 167)

On one hand, some researchers clajm there is no relationship; while on the other hand, it is claimed there is a definite relationship. Maddox reported that most teenagers view drinking as a means of demonstrating adulthood and that there was little evidence that teenagers drank as an expression of rebellion or hostility (11). Demone noted in his study that "a relatively small group of subjects were [sic] significantly involved in excessive drinking, crime, and delinquency...." (3, p. 3525) In a study by Wattenberg and Moir, "History Sheets," prepazed for juvenile offenders by the Youth Bureau of the Detroit Police Department were used (19). A comparison was made involving 141 white boys with records of arrest for being drunk with 9,555 white boys contacted by the police on other complaints. 
Only white boys were compared because of the total Negro group contacted by the police, only a few were in the drunk group. Also, 73 girls whose arrest zecords indicated involvement in drinking were compared with 1,081 giris whose records lacked this notation. Aside from stxong differences linked to age and some indication of weak inner resources, boys charged with drunkenness and girls involved in drinking were very similar to delinquents in general. A follow-up study was made of 96 boys whose records included a "drunk" notation. As young adults, approximately 10 per cent had police records including arrests for being drunk or committing crimes while drunk. Another 50 per cent had police records as adults which did not include a notation of drinking.

Mackay et al. found that 16 per cent of the delinquents studied were problem drinkers (8). They also found that all 20 problem drinkers had participated in fights while drinking. All but two of the boys reported some type of deviant behavior while under the influence of alcohol. However, only five had appeared in court on drunkenness charges. They also noted that the loss of impulse control after drinking may have led to the commission of delinquent acts, but there was insufficient evidence to establish a significant zelationship between the state of intoxication and the commission of delinquent acts. In the study by Mackay et a1, the following statement was made concerning the attitudes of the problem drinkers:

Although more than half of the 50 problem drinkers had been arrested for offenses committed after drinking, the majority of the group felt that their drinking had nothing to do with their presence at the Youth Service Board's Reception Center; neither did they consider themselves to be problem drinkers or express any concern about theix drinking practices. (7, p. 278) 
Blacker et al. found that the type of drinker correlated significantly with race and previous court involvement, but was not significantly related to social class. Boys without previous formal offenses were least likely to be found in the heavy, "relief," or "pathological" drinker categories (1)

\section{Summaxy}

It is probable that a large majority of teenagers will have used an alcoholic beverage at least once before graduating from high school. Studies show that 84 to 92 per cent of the teenagers tested reported that they have used an alcoholic beverage.

The reasons given for using alcoholic beverages emphasized sociability and self-expression. Most of the teenagers gave "to follow the crowd" as their reason for drinking, and most students began to drink some time during their fourteenth year. The results of the studies comparing delinquents with non-delinquents showed that delinquents were more likely to continue drinking after their first experience with alcohol, and much more evidence of sexious drinking behavior was detected among the delinquents than among the students. They also found that the delinquents drank for tension relief more frequently than did the non-delinquents.

The place of drinking was also different. The non-delinquents had their first drink in their homes with parental approval, while the delinquents drank outside their homes without parental approval.

There seems to be some relationship between drinking and 
juvenile lawlessness. Most studies in this area showed that those arrested, or those who had arrest records, also drank; however, there was insufficient evidence to establish a significant relationship between the state of intoxication and the commission of delinquent acts.

In conclusion, the literature suggests that delinquents drank sooner and more frequently than non-delinquents. They also drank for different reasons than the non-delinquents. 
CHAPTER III

\section{METHODS AND PROCEDURES}

In reviewing literature concerning the use of alcohol by adolescents, it became evident that little research had been published in reference to the drinking behavior of delinquent and non-delinquent youth. The writer, therefore, decided to investigate the behavior and attitudes of delinquent and non-delinquent youth and make a comparison between the two.

\section{Questionnaire}

A thorough review of literature was made in which questionnaires concerning drinking behavior had been used in a research project. Particularly useful were the projects of Blacker (1), Nelson (16), and Mackay (8).

A questionnaire was then constructed by the writer. It consisted of questions that covered four areas: (1) Family situation, (2) first experience with alcohol, (3) present drinking habits, and (4) attitudes toward drinking.

\section{Pre-test}

The questionnaire was administered to five classes of ninthgrade students at the Blackfoot L. D. S. Seminary, Blackfoot, Idaho. In discussion with the students, and after analysis of the results, it was decided that the questionnaire was too long and some questions were redundant. The redundant questions were eliminated and other were modified.

The questionnaire was then administered to five classes 
in the Brigham City West Seminary, Brigham City, Utah, for the purpose of testing the questionnaire for simplicity and clarity. The students were asked to comment on the questions they did not understand or could not answer with clarity. The results showed that some questions were ambiguous. Most students had marked more than one answer on some questions. The questions were again modified, and the questionnaire was finalized and printed.

\section{Population}

The population for the delinquents in this study was the entixe enrollment of the Youth Detention Homes in the states of Idaho and Utah. The non-delinquent population included students from selected secondary schools in Idaho. The schools selected were Pocatello Senior High School, Highland Senior High School, Alameda Junior High School, and Franklin Junior High School, all in Idaho.

\section{Administration of questionnaize}

Delinquent population. Through the cooperation of the superintendant of the Youth Training School (State Reform School) at St. Anthony, Idaho, the questionnaire was administered to the entire population of that institution. The questionnaires were administered on December 31, 1968. Approximately twenty students were home on leave. A total of 163 students was tested. The test was administered in the school's cafeteria. The students had just finished their noon meal and were still sitting at their assigned tables. The questionnaires were passed out by the writer with the assistance of the staff of the school. The staff acted as moniters for the testing period. The students 
were instructed to not put their names on the questionnaire. They were also told that theic questionnaire would be confidential and would in no way be made known or available to those in authority. They were informed that they could, therefore, be completely honest in their answers. These instructions were read to them from a typewritten page. (see Appendix B.) The students filled out the questionnaires. No questions were asked, nor was discussion allowed.

On January 6, 1969, the questionnaires were administered to the students of the Utah State Industrial School (State Reform School), Ogden, Utah. There were approximately 45 students who were off campus and did not participate in this study, making a total of 185 students answering the questionnaire. Of this total, 22 were not useable because of incomplete or inaccurate marking by the students. The questionnaire was administered immediately after the evening meal. The students remained at their assigned tables. The writer was again assisted by the institution's staff in passing out the materials and acting as monitors. The same instructions were read to them. The students filled out the questionnaires with no questions or discussion.

Non-delinquent population. After obtaining permission from Mr. Thomas Strah, Director of Secondary Education, Pocatello, Idaho, School District No, 25, the questionnaire was administered to 466 students in the senior and junior high schools in Pocatello. At the Pocatello Senior High School, the writer administered the questionnaire to sophomores in a Biology class. One of the school counselors administered the questionnaire to junior and 
seniox students in two history ciasses. Instructions were read to the students. The classes tested were selected by the counselor who stated a belief that the sample represented the total population of the school in attendance that day. The questionnaires were administered at $8: 30 \mathrm{a} \cdot \mathrm{m}$.

Next, the questionnaires were administered to sophomores, juniors, and seniors at the Highland High School located on the outskirts of Pocatello. The students were selected from history, government, and English classes by the counselor with the objective of gaining a representative sample of the population of the school. The questionnaires were administered to all the students at the same time. The students met in the cafetorium. The writer administered the questionnaire with the assistance of the counseling staff of the school. The questionnaire was administered at 10:30 a.m.

At the Alameda Junior High School located in a suburb of Pocatella, the questionnaires were administered prior to lunch in the school cafeteria to a sample group of seventh-, eighth-, and ninth-grade students from classes selected by the principal.

The questionnaires were administered at the Franklin Juniox High School located on the outskirts of Pocatello with the aid of the boys' counselor. The students came from classes selected by the counselor. The questionnaires were administered by the writer in the school cafeteria at 1:45 p.m. to all students at same time.

\section{Statistical analysis}

After administration of the questionnaires, the data were 
transferred to data processing cards, and the information on the cards was verified. This information was then processed by an IBM 360-44 Computer System. A Chi Square analysis was used in interpreting the data in an effort to find whether significant differences existed between the responses of the delinquents and the non-delinquents regarding their first drinking experience, their present drinking behavior, and their attitudes toward drinking. The Chi square analysis was used because:

Chi square is a test of significance. This statistic is a very useful one in research because no particular assumptions have to be made about the shape of the distributions of the frequencies being tested. It is most commonly used when data are in frequencies such as in the number of responses in different categories. It can be used with any data that can be reduced to proportions and percentages. The social psychologist involved in research upon the attitudes of people finds this statistic a very useful one. (4, p. 147)

It was felt that one of the most relevant items in this study was the determination of the frequency with which the Iespondents drank and whether the frequency of drinking was related to personal factors such as age and sex and social factors such as family structure and income. Therefore, the percentage of responses to the question concerning frequency of drinking was computed for the delinquent and non-delinquent groups by (1) age, (2) sex, (3) race, (4) family income, (5) area lived in, (6) with whom the students lived, (7) father's drinking behavior, and (8) nother's drinking behavior. 


\section{CHAPTER IV}

RESULTS

Of the 758 students studied, 292 , or 38.5 per cent, were detained in reform schools in the states of Idaho and Utah; 466 , or 61.4 per cent, were secondary school students in the Pocatello School District, Pocatello, Idaho. From this sample of delinquent and non-delinquent students, the following results were obtained:

\section{Age of students tested}

There were four students, or 0.5 per cent, who were 11 years of age at the time of this study; 64 , or 8.4 per cent, who were 12 years of age; 73 , or 9.6 per cent, who were 13 years of age; 106, or 13.9 per cent, who were 14 years of age; 115 , or 15.1 per cent, who were 15 years of age; 161 , or 21.2 per cent, who were 16 years of age; 157 , or 20.7 per cent, who were 17 years of age; 70 , or 9.2 per cent who were 18 years of age; and 8 , or 1.0 per cent, who were 19 years of age ox older. In comparing the differences between the delinquents and the non-delinquents, it should be noted that the majority of the delinquents ( 58.8 per cent) was between the ages of 16 and 17 at the time of this study, while the non-delinquents were distributed fairly evenly between the ages of 12 to 18 . (See Table 1)

\section{Sex of students tested}

Of the 758 students tested, 424 , or 55.9 per cent, were male; and 334 , or 44.0 per cent, were female. Ninety, or 30.8 per cent, 
Table 1. Present age of selected sample of delinquents and non-delinquents

\begin{tabular}{ccccccc}
\hline $\begin{array}{c}\text { Present } \\
\text { Age }\end{array}$ & $\begin{array}{l}\text { Delinquents } \\
\text { No. }\end{array}$ & $\%$ & \multicolumn{2}{c}{$\begin{array}{c}\text { Non-delinquents } \\
\text { No. }\end{array}$} & $\begin{array}{c}\text { Total } \\
\text { No. }\end{array}$ & $\%$ \\
\hline 11 & 4 & 1.3 & 0 & 0.0 & 4 & 0.5 \\
12 & 6 & 2.0 & 58 & 12.4 & 64 & 8.4 \\
13 & 5 & 1.7 & 68 & 14.5 & 73 & 9.6 \\
14 & 27 & 9.2 & 79 & 16.9 & 106 & 13.9 \\
15 & 43 & 14.7 & 72 & 15.4 & 115 & 15.1 \\
16 & 89 & 30.4 & 72 & 15.4 & 161 & 21.2 \\
17 & 83 & 28.4 & 75 & 16.0 & 157 & 20.7 \\
18 & 31 & 10.6 & 39 & 8.3 & 70 & 9.2 \\
19 & 4 & 1.3 & 4 & 0.8 & 8 & 1.0 \\
\hline
\end{tabular}

of the delinquents tested were female; and 202, or 69.1 per cent, were male. Of the 466 non-delinquents, 222 , or 47.6 per cent, were males; and 244 , or 52.3 per cent, were females. (See Table 2)

\section{Race of students tested}

There were 662 , ox 87.3 per cent, who were Caucasian; 39, or 5.1 per cent, were Indian; 12, or 1.5 per cent, were Negro; and 41, or 5.4 per cent, were Mexican. Two hundred and thirteen, or 72.9 per cent, of the 292 delinquents were Caucasian; 35, or 11.9 per cent, were Indian; 8 or 2.7 per cent, were Negro; and 35 , or 11.9 per cent, were Mexican. In the non-delinquent group, 449, or 96.3 per cent, of the students were Caucasian; 4, or 0.8 per cent, were Indian; 4 , or 0.8 per cent, were Negro; and 6 , or 1.2 per cent were Mexican. (See Table 2) 
Table 2. Descriptive background of a selected group of delinquent and non-delinquent juveniles

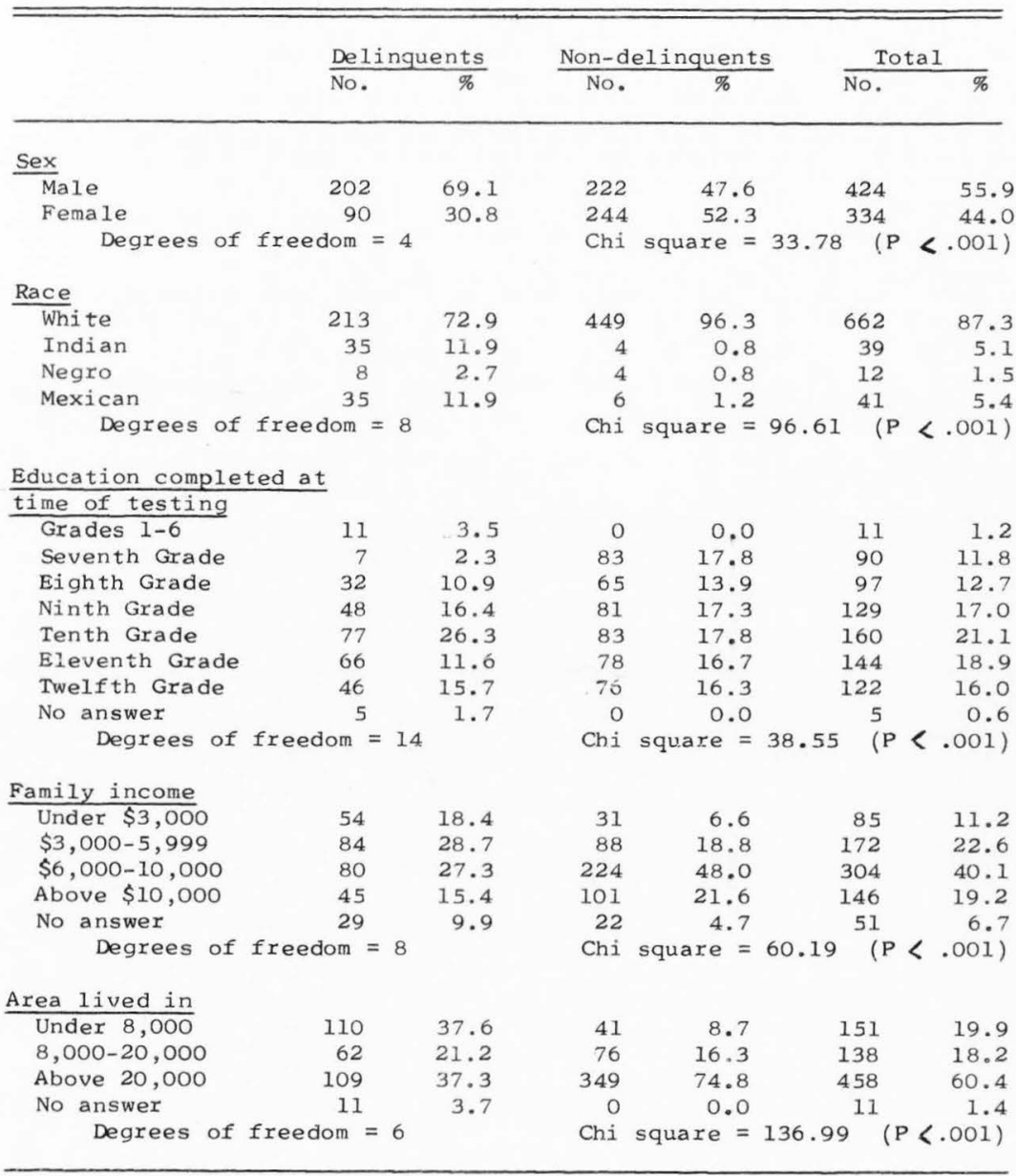




\section{Education of students tested}

Of the total number tested, 11 , or 1.2 per cent, had a sixth-grade education or less; 90 , or 11.8 per cent, were in the seventh grade; 97 , ox 12.7 per cent, were in the eighth grade; 129, or 17.0 per cent, were in the ninth grade; 160 , or 21.1 per cent were in the tenth grade; 144 , or 18.9 per cent, were in the eleventh grade; and 122 , or 16.0 per cent, were in the twelfth grade. There were 5, oz 0.6 per cent, who did not answer this question. There was a significant difference at the .001 per cent level between levels of education of the delinquent and non-delinquent groups. The non-delinquent group was equally divided among the seventh through twelfth grade, with only a 4 per cent difference in the lowest per cent and the highest per cent which occurred in the eighth grade and tenth grade respectively. On the other hand, the education of the delinquents was clustered in the ninth, tenth, and eleventh grades, with 3.5 per cent of the delinquents completing only six grades or less of formal education. Only 2,3 per cent were in the seventh grade at the time of testing. (See Table 2)

\section{Family income of students tested}

As to the question of family income, 85 , or 11.2 per cent, ranked their family income as under $\$ 3,000$ for the year; 172 , or 22.6 per cent ranked their family as having a yearly income of between $\$ 3,000$ and $\$ 5,999 ; 304$, or 40.1 per cent, ranked their yearly family income as between $\$ 6,000$ and $\$ 10,000$; and 146 , or 19.2 per cent ranked their yearly family income as over $\$ 10,000$. There were 51, or 6.7 per cent, who gave no answer to this 
question. In the delinquent group, 56.0 per cent stated

that their family income ranged between $\$ 3,000$ and $\$ 10,000$.

Forty-eight per cent of the non-delinquents stated that their family income ranged between $\$ 6,000$ and $\$ 10,000$; with 15.4 per cent of the delinquents stating theiz family income was above $\$ 10,000$ in comparison with 21.6 per cent of the non-delinquents. In the axea of family income, there was a significant difference at the .001 per cent level. (See Table 2)

\section{Area lived in}

As to the type of area in which the family lived, 11, or 1.4 per cent failed to answer this question; 151, or 19.9 per cent, stated they lived in an area with a population of under 8,000; 138, or 18.2 per cent, lived in an area with a population between 8,000 and 20,000 people; and 458 , or 60.4 per cent stated they lived in an area with a population of over 20,000 people. The majority of non-delinquents, 74.8 pex cent, lived in areas above 20,000 people in population; and 37.6 per cent of the delinquents lived in areas under 8 , 000 in population, and 37.3 per cent 1 ived in areas above 20,000 in population. The diffexence found was significant at the .001 pex cent level. (See Table 2)

\section{With whom the students lived}

Five hundred and fifty-seven, or 73.4 per cent, of the students stated they lived with both parents; 26 , or 3.4 per cent, lived with theix fathers only; 121, or 15.9 pez cent, lived with their mother only; and 53, ox 6.9 per cent, stated they lived with neither their father nor their mother. There was only one 
student who failed to answer this question. The majority of the delinquents, 53.7 per cent, and the majority of the nondelinquents, 85.8 per cent, lived with both parents. Twentyfive per cent of the delinquents Iived with their mothers only in comparison with 10.3 pex cent of the non-delinquents who lived with their mother only. There was also a higher percentage of delinquents living with neither their father nor their mother, 14.3 per cent, in comparison with only 2.3 per cent of the non-delinquents. The differences in this area were significant at the .001 per cent level. (See Table 3)

Table 3. With whom the students lived at home.

\begin{tabular}{|c|c|c|c|c|c|c|c|}
\hline & \multicolumn{2}{|c|}{ Delinquents } & \multicolumn{2}{|c|}{ Non-delinquents } & \multicolumn{3}{|c|}{ Total } \\
\hline & No. & $\%$ & No. & $\%$ & $\overline{\mathrm{No}}$ & & $\%$ \\
\hline Both parents & 157 & 53.7 & 400 & 85.8 & 55 & & 73.4 \\
\hline Father only & 19 & 6.5 & 7 & 1.5 & & & 3.4 \\
\hline Mother only & 73 & 25.0 & 48 & 10.3 & 12 & & 15.9 \\
\hline Neither & 42 & 14.3 & 11 & 2.3 & & & 6.9 \\
\hline $\begin{array}{l}\text { No answer } \\
\text { Degrees }\end{array}$ & $\mathrm{Im}^{1}=$ & 0.3 & $\begin{array}{r}0 \\
\text { Chi }\end{array}$ & $\begin{array}{r}0.0 \\
r e=\end{array}$ & 24 & & $\begin{array}{c}0.1 \\
(.001)\end{array}$ \\
\hline
\end{tabular}

Drinking habits of father

As to the question concerning the frequency with which the father drinks, there were 237 , or 31.2 per cent who stated their fathers never drink; 95, or 12.5 per cent said their fathers drink once or twice a year; 61 , or 8.0 per cent, stated once every 2 to 5 months; 49 , ox 6.4 per cent, stated once every month; 58, or 7.6 pex cent, stated 2 or 3 times a month; 64 , or 
Table 4. Frequency of parents' drinking

\begin{tabular}{|c|c|c|c|c|c|c|}
\hline \multirow{2}{*}{, } & \multicolumn{2}{|c|}{ Delinquents } & \multicolumn{2}{|c|}{ Non-delinquents } & \multicolumn{2}{|c|}{ Total } \\
\hline & No. & $\%$ & No. & $\%$ & No. & $\overline{\%}$ \\
\hline \multicolumn{7}{|l|}{ Father } \\
\hline Never & 72 & 24.6 & 165 & 35.4 & 237 & 31.2 \\
\hline Once or twice a yr. & 33 & 11.3 & 62 & 13.3 & 95 & 12.5 \\
\hline Once every $2-5$ mos. & 16 & 5.4 & 45 & 9.6 & 61 & 8.0 \\
\hline Once every month & 21 & 7.1 & 28 & 6.0 & 49 & 6.4 \\
\hline $2-3$ times a month & 28 & 9.5 & 30 & 6.4 & 58 & 7.6 \\
\hline Once a week & 28 & 9.5 & 36 & 7.7 & 64 & 8.4 \\
\hline Several times a wk. & 33 & 11.3 & 47 & 10.0 & 80 & 10.5 \\
\hline Every day & 29 & 9.9 & 31 & 6.6 & 60 & 7.9 \\
\hline No answer & 32 & 10.9 & 22 & 4.7 & 54 & 7.1 \\
\hline Degrees of free & $o m=16$ & & square & $=27.05$ & $(\mathrm{P}<$. & \\
\hline \multicolumn{7}{|l|}{ Mother } \\
\hline Never & 109 & 37.3 & 217 & 46.5 & 326 & 43.0 \\
\hline Once or twice a yr. & 42 & 14.3 & 82 & 17.5 & 124 & 16.3 \\
\hline Once every $2-5$ mos. & 15 & 5.1 & 38 & 8.1 & 53 & 6.9 \\
\hline Once every month & 18 & 6.1 & 24 & 5.1 & 42 & 5.5 \\
\hline $2-3$ times a month & 23 & 7.8 & 33 & 7.0 & 56 & 7.3 \\
\hline Once a week & 15 & 5.1 & 29 & 6.2 & 44 & 5.8 \\
\hline Several times a wk. & 18 & 6.1 & 31 & 6.6 & 49 & 6.4 \\
\hline Every day & 18 & 6.1 & 9 & 1.9 & 27 & 3.5 \\
\hline No answer & 34 & 11.6 & 3 & 0.6 & 37 & 4.8 \\
\hline Degrees of free & $o m=16$ & & square & 61.48 & $(\mathrm{P}<$. & 1) \\
\hline
\end{tabular}

8.4 per cent, stated once a week; 80 , or 10.5 per cent, stated several times a week; and 60 , or 7.9 per cent, stated that their fathers drank every day. There were 54, or 7.1 per cent, who did not answer this question. There was a different at the .05 per cent level of significance in the drinking habits of the fathers of the delinquents and the drinking habits of the fathers of the non-delinquents. A higher percentage of the non-delinquents' fathers never drank, 35.4 per cent, in comparison with 24.6 per cent of the delinquents' fathers. The delinquents' fathers drank most frequently several times a week, 11.3 per cent, or once or twice a year, 13.3 per cent. The rest of the percentages were scattered quite evenly among the other categories. (See Table 4) 
Drinking habits of mother

Regarding the frequency with which the mother drinks, 326, or 43.0 per cent, stated their mothers never drank; 124 , or 16.3 per cent stated they drank once or twice a year; 53, or 6.9 per cent stated once every 2 to 5 months; 42 , or 5.5 per cent stated once every month; 56, or 7.3 per cent stated 2 or 3 times a month; 44 , or 5.8 per cent, stated once a week; 49 , or 6.4 per cent stated several times a week; and 27 , or 3.5 per cent stated thei $x$ mothers drank every day. There were 37, or 4.8 per cent, who did not answer this question. A difference between the delinquents and non-delinquents at the .001 per cent level was found in the drinking habits of the mothers. The delinquents stated that 37.3 per cent of their mothers never drank in comparison with 46.5 per cent of the non-delinquents' mothers who never drank; 14.3 per cent of the delinquents' mothers drank only once or twice a year, with 6.1 per cent stating their mothers drank several times a week and 6.1 per cent stating their mothers drank every day. In comparison, 17.5 per cent of the non-delinquents' mothers drank once or twice a year, and 6.6 per cent drank several times a week. Only 1.9 per cent drank every day. The other percentages were scattered quite evenly among the remainder of the categories. (See Table 4)

\section{Factors concerning first drink}

Age of first drink. As to the age of first drink, there were 221 , or 29.1 per cent, of the students tested who had never taken their first drink; 45, or 5.9 per cent, took their first 
Table 5. Age of first drink

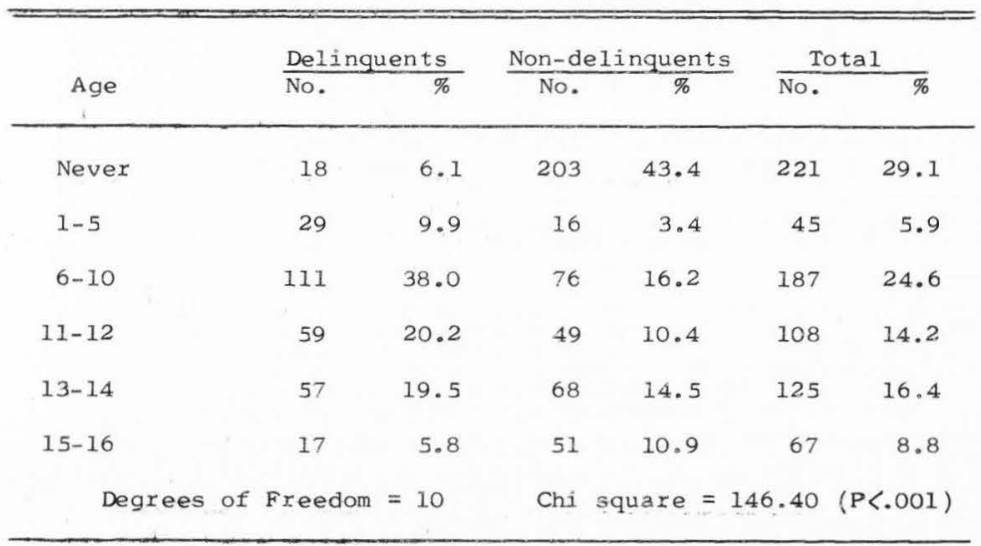

drink between the ages of 1 and $5 ; 187$, or 24.6 per cent took their first drink between the ages of 6 and 10 ; 108 , or 14.2 per cent took their first drink between the ages of 11 and 12 ; 125, or 16.4 per cent took their first drink between the ages of 13 and 14; and between the ages of 15 and 16,67 , or 8.8 per cent, took their first drink. The majority of the delinquents, 38.0 per cent, took their first drink between the ages of 6 and 10; and the majority of the non-delinquents, 16.2 per cent, took their first drink between the ages of 6 and 10. There were 19.5 per cent of the delinquents who took their first drink between the ages of 13 and 14 , compared to 14.5 per cent of the non-delinquents who took their first drink between the ages of 13 and $14 ; 20.2$ per cent of the delinquents took their first drink between the ages of 11 and 12 , compared with 10.4 per per cent of the delinquents who took their first drink between the ages of 11 and 12 . There was a significant difference at the .001 per cent level between these two groups. (See Table 5) 
Type of first drink. Concerning the type of alcoholic beverage first drank by the students, 324 , or 42.7 per cent, stated their first drink was beer; 81 , or 10.6 per cent, stated their first drink was wine; 132, or 17.4 per cent, said their first drink was whiskey; 218 , or 28.8 per cent, stated they had not yet had their first drink. I wo, or 0.2 per cent, failed to answer this question. Beer was the first alcoholic beverage drank by 55.8 per cent of the delinquents in comparison with 34.5 per cent of the non-delinquents who drank beer. The next most popular drink for the delinquents was whiskey (28.0 per cent), but the next most popular beverage for the non-delinquents was wine. Only 5.1 per cent of the delinquents stated they never drank in comparison with 43.5 per cent of the non-delinquents who stated they never drank. A significant difference was found at the .001 per cent level. (See Table 6)

Parents' permission. Two hundred and sixteen students, or 28.4 per cent, of the students stated they did have their parents' permission to take their first drink, while 319, or 42. 0 per cent, did not have their parents' permission. Five students, or 0.6 per cent failed to answer this question. The majority of the delinquents did not have their parents' permission to take their first drink (68.8 per cent), compared with 25.4 per cent of the non-delinquents who did not have their parents' permission. On the other hand, the majority of the non-delinquents did have their parents' permission ( 31.1 percent), compared with 24.3 per cent of the delinquents. The differences found were significant at the .001 per cent level. (See Table 6) 
Table 6. Factors concerning first drink of delinquents and non-delinquents

\begin{tabular}{|c|c|c|c|c|c|c|}
\hline & \multicolumn{2}{|c|}{ Delinquents } & \multicolumn{2}{|c|}{ Non-delinquents } & \multicolumn{2}{|c|}{ Total } \\
\hline & No. & $\%$ & No. & $\%$ & No. & $\%$ \\
\hline \multicolumn{7}{|l|}{ What was first drink } \\
\hline Beer & 162 & 55.8 & 162 & 34.5 & 324 & 42.7 \\
\hline Wine & 29 & 9.9 & 52 & 11.1 & 81 & 10.6 \\
\hline Whiskey & 82 & 28.0 & 50 & 10.7 & 132 & 17.4 \\
\hline Other & 1 & 0.3 & 0 & 0.0 & 1 & 0.1 \\
\hline I don't drink & 15 & 5.1 & 203 & 43.5 & 218 & 28.7 \\
\hline No answer & 2 & 0.6 & 0 & 0.0 & 2 & 0.2 \\
\hline Degrees of free & dom $=$ & & Chi & square $=$ & $75 \quad(1$ & $(.001)$ \\
\hline \multicolumn{7}{|l|}{ Parents' permission } \\
\hline Yes & 71 & 24.3 & 145 & $31: 1$ & 216 & $28 \cdot 4$ \\
\hline No & 201 & 68.8 & 119 & 25.4 & 319 & 42.0 \\
\hline I don't drink & 15 & 5.1 & 203 & 43.4 & 218 & 28.7 \\
\hline No answer & 5 & 1.7 & 0 & 0.0 & 5 & 0.6 \\
\hline Degrees of free & dom $=$ & & Chi & square $=$ & $82 \quad($ & $(.001)$ \\
\hline \multicolumn{7}{|l|}{ Where did you have } \\
\hline \multicolumn{7}{|l|}{ first drink } \\
\hline Own home & 83 & 28.4 & 138 & 29.5 & 220 & 29.0 \\
\hline Home of friend & 92 & 31.5 & 57 & 12.2 & 149 & 19.6 \\
\hline $\begin{array}{l}\text { Restaurant, tavern, } \\
\text { or bar }\end{array}$ & & & & & & \\
\hline Night club & $\begin{array}{l}9 \\
6\end{array}$ & $\begin{array}{l}3.0 \\
2.0\end{array}$ & 0 & $\begin{array}{l}1.4 \\
0.0\end{array}$ & $\begin{array}{r}16 \\
6\end{array}$ & $\begin{array}{l}2.1 \\
0.7\end{array}$ \\
\hline Automobile & 66 & 22.6 & 41 & 8.7 & 107 & 14.1 \\
\hline \multicolumn{7}{|l|}{ Private club or } \\
\hline high school dance & 12 & 4.0 & 6 & 1.2 & 18 & 2.2 \\
\hline Relative's home & 9 & 3.0 & 14 & 2.9 & 23 & 3.0 \\
\hline I don't drink & 15 & 5.1 & 203 & 43.4 & 218 & 28.7 \\
\hline No answer & 0 & 0.0 & 1 & 0.2 & 1 & 0.1 \\
\hline Degrees of freec & dom $=$ & & Chi & square $=1$ & 101 & $.001)$ \\
\hline \multicolumn{7}{|l|}{ Whom were you with } \\
\hline Parents & 48 & 16.4 & 122 & 26.1 & 170 & 22.4 \\
\hline Relative & 30 & 10.2 & 28 & 5.9 & 58 & 7.6 \\
\hline Boyfriend (s) & 110 & 37.6 & 70 & 14.9 & 180 & 23.7 \\
\hline Girlfirend(s) & 44 & 15.0 & 25 & 5.3 & 68 & 8.9 \\
\hline Boys and girls & 25 & 8.5 & 10 & 2.1 & 35 & 4.6 \\
\hline Alone & 19 & 6.5 & 8 & 1.7 & 27 & 3.5 \\
\hline I don't drink & 15 & 5.1 & 203 & 43.4 & 218 & 28.7 \\
\hline No answer & 0 & 0.0 & 0 & 0.0 & 0 & 0.0 \\
\hline Degrees of & $\mathrm{om}=$ & & Chi & square = & 76 & $(.001)$ \\
\hline
\end{tabular}


$\frac{\text { Delinquents }}{\text { No. }}$

$\frac{\text { Non-delinquents }}{\text { No. }}$

$\frac{\text { Total }}{\text { No. } \%}$

How was first drink

obtained

18

6.1

9

1.9

27

3.5

14.3

13

2.7

55

7.2

Friend gave it to me 81

27.7

67

14.3

19.3

Parent gave it to me 44

15.0

115

24.6

147

20.9

Relative gave it

to me
older person bought

8.9

32

6.8

7.6

$62 \quad 21.2$

27

5.7

58

11.7

I don't drink

5.1

203

43.4

89

28.7

No answer.

$0 \quad 0.0$

0.0

218

0.0

Degrees of freedom $=14$

Chi. square $=173.06$

$(\mathrm{P}<.001)$

Reason for taking first

\begin{tabular}{|c|c|c|}
\hline drink & & \\
\hline To feel grown up & 13 & 4.4 \\
\hline Just for "kicks" & 111 & 38.0 \\
\hline To "show off" & 5 & 1.7 \\
\hline Special occasion & 19 & 6.5 \\
\hline For courage & 3 & 1.0 \\
\hline Because friends di & 18 & 6.1 \\
\hline Depression & 9 & 3. \\
\hline $\begin{array}{l}\text { Others expected th } \\
\text { to }\end{array}$ & $\mathrm{em}$ & 1. \\
\hline Family custom & 17 & 5.8 \\
\hline To get up nerve & 4 & 1.3 \\
\hline Curiosity & 63 & 21.5 \\
\hline Other & 10 & 3.4 \\
\hline I don't drink & 15 & \\
\hline No answer. & 1 & 0 . \\
\hline Degrees of fre & edom $=26$ & \\
\hline How soon after first & drink & \\
\hline did you drink again & & \\
\hline Less than one week & 132 & 45.2 \\
\hline One week & 31 & 10.6 \\
\hline Two weeks & 25 & 8.5 \\
\hline One month & 28 & 9.5 \\
\hline Six months & 23 & 7.8 \\
\hline One year & 27 & 9.2 \\
\hline Nevex & 7 & 2.3 \\
\hline I don't drink & 17 & 5.8 \\
\hline No answer & 2 & \\
\hline
\end{tabular}

Degrees of freedom $=16$

$\begin{array}{rrrr}4 & 0.8 & 17 & 2.2 \\ 42 & 8.9 & 153 & 20.1 \\ 3 & 0.6 & 8 & 1.0 \\ 53 & 11.3 & 72 & 9.4 \\ 1 & 0.2 & 4 & 0.5 \\ 5 & 1.0 & 23 & 3.0 \\ 7 & 1.4 & 16 & 2.1 \\ & & & \\ 2 & 0.4 & 6 & 0.7 \\ 11 & 2.3 & 28 & 3.6 \\ 0 & 0.0 & 4 & 0.5 \\ 132 & 28.2 & 194 & 25.5 \\ 3 & 0.6 & 13 & 1.7 \\ 203 & 43.4 & 218 & 28.7 \\ 1 & 0.2 & 2 & 0.2 \\ \text { Chi } & \text { square }=228.83 \quad(P<.001)\end{array}$

Chi square $=228.83 \quad(\mathrm{P}<.001)$

$\begin{array}{rrr}28 & 5.9 & 160 \\ 15 & 3.2 & 46 \\ 14 & 2.9 & 39 \\ 56 & 11.9 & 83 \\ 41 & 8.7 & 64 \\ 68 & 14.5 & 95 \\ 36 & 7.7 & 43 \\ 207 & 44.3 & 224 \\ 2 & 0.4 & 4\end{array}$

Chi square $=262.41$

$\begin{array}{rr}160 & 21.1 \\ 46 & 6.0 \\ 39 & 5.1 \\ 83 & 10.9 \\ 64 & 8.4 \\ 95 & 12.5 \\ 43 & 5.6 \\ 24 & 29.5 \\ 4 & 0.5\end{array}$

$(P<.001)$ 
Where fizst drink was taken. Concerning the question of where the first drink was taken, 220, or 29.0 per cent had their first drink in their own home; 149, or 19.6 per cent had it at the home of a friend; 16 , or 2.1 per cent, had it in a restaurant, tavern, or bar; 6 , ox 0.7 per cent, had it in a night club; 107, or 14.1 per cent, had it in an automobile; 18, or 2.2 per cent had it in a private club or at a high school dance; 23 , or 3.0 per cent, had it at a relative's home; and only 1, or 0.1 per cent, failed to answer the question. A significant difference was found at the .001 per cent level between the delinquents and the non-delinquents as to the place they partook of theix first drink. At their own home is where 28.4 per cent of the delinquents took their first drink compared with 29.5 per cent of the non-delinquents who took their first drink at their own home; 31.5 per cent of the delinquents took their first drink at the home of a friend; and 22.6 per cent of the delinquents took their first drink in an automobile. On the other hand, 12.2 per cent of the non-delinquents took their first drink at the home of a friend, and 8.7 per cent took their first drink in an automobile. Whom they were with. To the question with whom were they with when they had theiz first drink, 170, or 22.4 per cent, were with their parents; 58, or 7.6 per cent, were with a relative; 180 , or 23.7 per cent, were with boyfriends; 68 , or 8.9 per cent, were with girlfriends; 35 , or 4.6 per cent, were with both boys and gixis; and 27 , or 3.5 per cent, were alone. The majority of the non-delinquents (26.1 per cent) took their first drink with their parents, while 37.6 per cent 
of the delinquents took their first drink with boyfriends, and 15.0 per cent of the delinquents took their first drink with girlfriends. This compares with 14.9 pez cent of the nondelinquents who took their first drink with boyfriends and 5.9 per cent who took their first drink with girifriends. Only 16.4 per cent of the delinquents took their first drink with their parents. There is a significant difference at the .001 per cent level between the delinquent and the non-delinquent groups as to whom they were with when they had their first drink. (See Table 6)

How first drink was obtained. Twenty-seven, or 3.5 per cent, bought their first drink themselves; 55 , or 7.2 per cent, stole it; 147 , or 19.3 per cent stated a friend gave it to them; 159, or 20.9 per cent, said their parents gave it to them; 58, or 7.6 per cent, stated a relative gave it to them; and 89, or 11.7 per cent, said an older person bought theil first drink for them. There were 24.6 per cent of the non-delinquents who stated they received their first drink from their parents, and 15.0 per cent of the delinquents received their first drink from their parents. There were 14.3 per cent of the delinquents who stole their first drink in comparison to 2.7 per cent of the non-delinquents who stole theil first drink. The highest percentage of delinquents, 27.7 per cent, said a friend gave them their first drink. These differences were significant at the .001 per cent level. (See Table 6)

Reason for taking first drink. Seventeen, or 2.2 per cent, took their first drink to feel grown up; 153, or 20.1 per cent, took it just for "kicks"; 8, or 1.0 pex cent, took their first drink to "show off"; 72 , or 9.4 per cent, took it for special 
occasions; 4 , or 0.5 per cent, took it for courage; 23 , or 3.0 per cent took it because their friends did; 16, or 2.1 per cent, took it for depression: 6 , or 0.7 per cent, took it because others expected them to; 28 , or 3.6 per cent, took it because it was a family custom; 4 , or 0.5 per cent, took it to "get up nerve', 194, or 25.5 per cent, took their first drink because of curiosity; 13, or 1.7 per cent, stated other reasons for taking their first drink. The majority of the delinquents (38.0 per cent) took their first drink just for "kicks," while the majority of the non-delinquents (28.2 per cent) took their first drink out of curiosity. Again, there was a significant difference at the .001 per cent level between the delinquents and the non-delinquents. (See Table 6)

\section{Factors concerning present drinking behavior}

\section{Present frequency of drinking. To the question how} frequently they presently drank alcoholic beverages on the average, 109 , or 14.3 per cent, stated they drank several times a week; 71 , or 9.3 per cent drank two or three times a month; 90 , or 11.8 per cent, drank once a week; 47 , or 6.2 per cent, drank once a month; 63 , or 8.3 per cent drank about every two to five months; 65 , or 8.5 per cent, drank once or twice a year; 30 , or 3.9 per cent, drank over one year; and 282 , or 37.2 per cent, stated they presently didn't drink. One person did not respond to this question. The differences found were significant at the .0O1 per cent level. (See Table 7)

There were 45.2 per cent of the delinquents who stated they took a second drink in less than one week after their first 
Table 7. Present drinking behavior of delinquents and non-delinquents

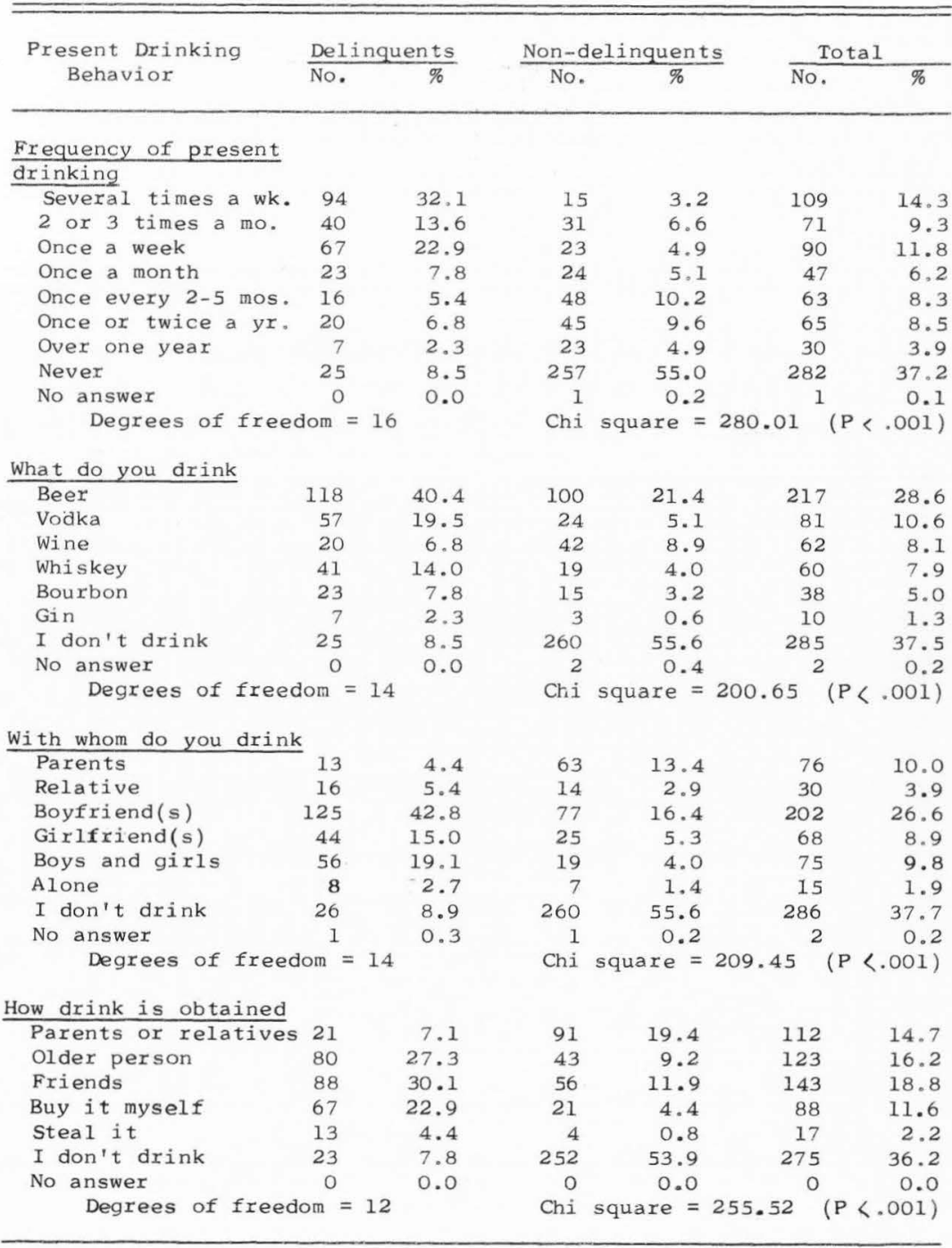


drink of alcohol, with only 5.9 per cent of the non-delinquents taking a second drink within one week. The majority of the non-delinquents ( 14.5 per cent) stated they took their second drink at least one year after their first drink. There were 7.7 per cent of the non-delinquents who stated they never drank again after their first drink of alcohol. In comparison, 2.3 per cent of the delinquents stated they never drank again after their initial drink of alcohol; 11.9 per cent of the non-delinquents took a second drink one month after their initial drink, and 10.6 per cent of the delinquents took their second drink one week after their initial drink of alcohol. The differences found were significant at the .001 per cent level. (See Table 6)

Type of drink presently used most frequently. Beer was the alcoholic beverage used most frequently by 217 , or 28.6 per cent, of the students tested; 81 , or 10.6 per cent, drank vodka most frequently; 62 , or 8.1 per cent, drank wine; 60 , or 7.9 per cent, drank whiskey; 38, or 5.0 per cent drank bourbon; 10, or 1.3 per cent, drank gin; and 2 students failed to respond to this question. The majority of both the delinquents ( 40.4 per cent) and the non-delinquents (21.4 per cent) drank. beer most frequently: 19.5 per cent of the delinquents stated they drank vodka compared with only 5.1 per cent of the nondelinquents. Whereas 8.9 per cent of the non-delinquents stated they drank wine compazed with 6.8 per cent of the delinquents, 14.0 per cent of the delinquents stated they drank whiskey most frequently. Again, there was a significant difference at the .001 per cent level. (See Table 7) 
Present drinking companion. Seventy-six, or 10.0 per cent, of the students tested usually drank with their parents: 30 , or 3.9 per cent, usually drank with their relatives; 202 , or 26.6 per cent drank with theit boyfriends; 68 , or 8.9 per cent, drank with their girlfriends; 75 , or 9.8 per cent, drank with both boys and gidis; 15, or 1.9 per cent, usually drank alone; and 4 , or 0.5 per cent, drank with others not specifically listed on the questionnaire. Two, or .02 pex cent, failed to answer this question. The most popular companion for drinking for both the delinquents and the nondelinquents was boyfriends--42.8 per cent of the delinquents and 16.4 pex cent of the non-delinquents. The second highest group for: the non-delinquents was parents (1.3. 4 per cent). On the other hand, 15.0 per cent of the delinquents drank with girlfriends, and 19.1 per cent drank with both boyfriends and girlfriends. Only 4.4 pex cent of the delinquents drank with their parents most of ten. (See Table 7)

How drink is presently obtajned. One hundred and twleve, or 14.7 per cent, got their alcoholic beverages from parents or relatives; 123, or 16.2 pex cent, had an older person get it for them; 143, or 18.8 per cent had friends give it to them; 88 , or 11.6 per cent, bought it themselves; and 17, ox 2.2 per cent, stole it. Friends gave alcoholic beverages to 30.1 per cent of the delinquents, and 27.3 per cent of the delinquents received theix alcoholic beverages from older persons; 19.4 per cent of the non-delinquents stated their parents gave them the alcoholic beverages they drank. Oniy 9.2 per cent of the 
non-delinquents received their drinks from older persons, and 11.9 per cent received them from friends. The differences were significant at the .001 per cent level. (See Table 7)

\section{Influence of alcohol on behavior}

Have you ever passed out? One hundred and seventy-six, or 23.2 per cent, stated they had passed out while drinking; and 321 , or 42.3 per cent, said they had not passed out while drinking. In comparing delinquents and non-delinquents, 45.5 per cent of the delinquents stated they had passed out, while only 9.2 per cent of the non-delinquents stated they had passed out while drinking. The differences found were significant at the .001 pex cent level. (See Table 8)

Were you ever unable to remember? To the question were they ever unable to remember where they were or what they were doing while drinking, 195, or 25.7 per cent of the students tested said "yes"; and 298, or 39.3 per cent, said "no " Two students did not answex this question. In comparing the delinquents and non-delinquents, 44.8 pex cent of the delinquents stated they were unable to remember where they were or what they were doing while under the influence of alcohol, compared with 13.7 per cent of the non-delinquents answering "yes" to this question. The difference found was significant at the .001 per cent level. (See Table 8)

Arrested for drinking. One hundred and twenty-six, or 16.6 per cent, stated "yes" they had been arrested for drinking; and 369 , or 48.6 per cent, said "no" they had not been arrested for drinking. Crimes were committed by 43.1 per cent of the delinquents who had been drinking alcoholic beverages in 
Table 8. Influence of alcohol on behavior of delinquents and non-delinquents

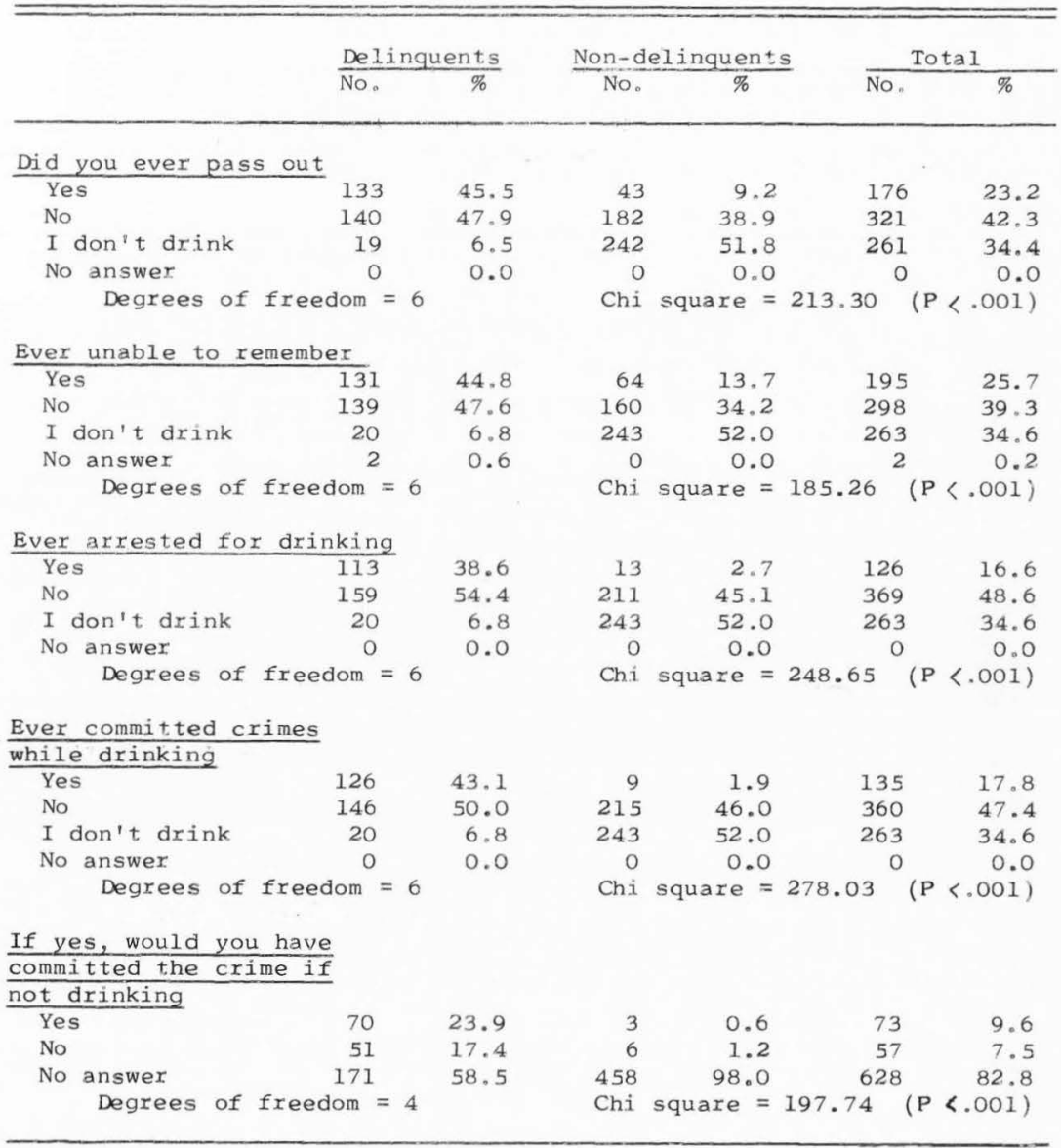


comparion with only 1.9 per cent of the non-delinquents. Of the total number answering "yes" they had committed crimes, 73, or 9.6 per cent, said they would have committed the crimes had they not been drinking; and 57 , or 7.5 per cent, said they would not have committed the crimes had they not been drinking. Of the delinquents who said they had committed a crime while drinking alcohol, 23.9 per cent of the delinquents stated they felt they would have committed the crime even if they had not been drinking alcohol. This is in comparison to only 0.6 per cent of the non-delinquents who felt they would have committed the crime anyway, with 1.2 per cent stating they would not have committed the crime had they not been drinking alcohol. These differences were significant at the .001 per cent level. (See Tab1e 8)

\section{Opinions concerning drinking of alcoholic beverages}

Opinion toward drinking. To the question how they felt about drinking alcoholic beverages, 186 , or 24.5 per cent, felt there was nothing wrong with it; 309 , or 40.7 per cent felt it was all right if not in excess; 131 , or 17.2 per cent, felt it was physically harmful; 122 , or 16.0 per cent, felt it was morally wrong. Ten students, or 1.3 per cent, failed to state their opinion. In comparing the delinquents and the non-delinquents, 49.3 per cent of the delinquents stated there was nothing wrong with drinking, 35.9 per cent felt it was all right if not in excess; 43.8 per cent of the non-delinquents stated that it was all right if not in excess; 23.7 pex cent felt it was physically harmful; and 22.2 per cent felt it was morally wrong for people to drink. The differences were significant at the .001 per cent level. (See Table 9) 
Table 9. Opinions of delinquents and non-delinquents on questions concerning the drinking of alcoholic beverages

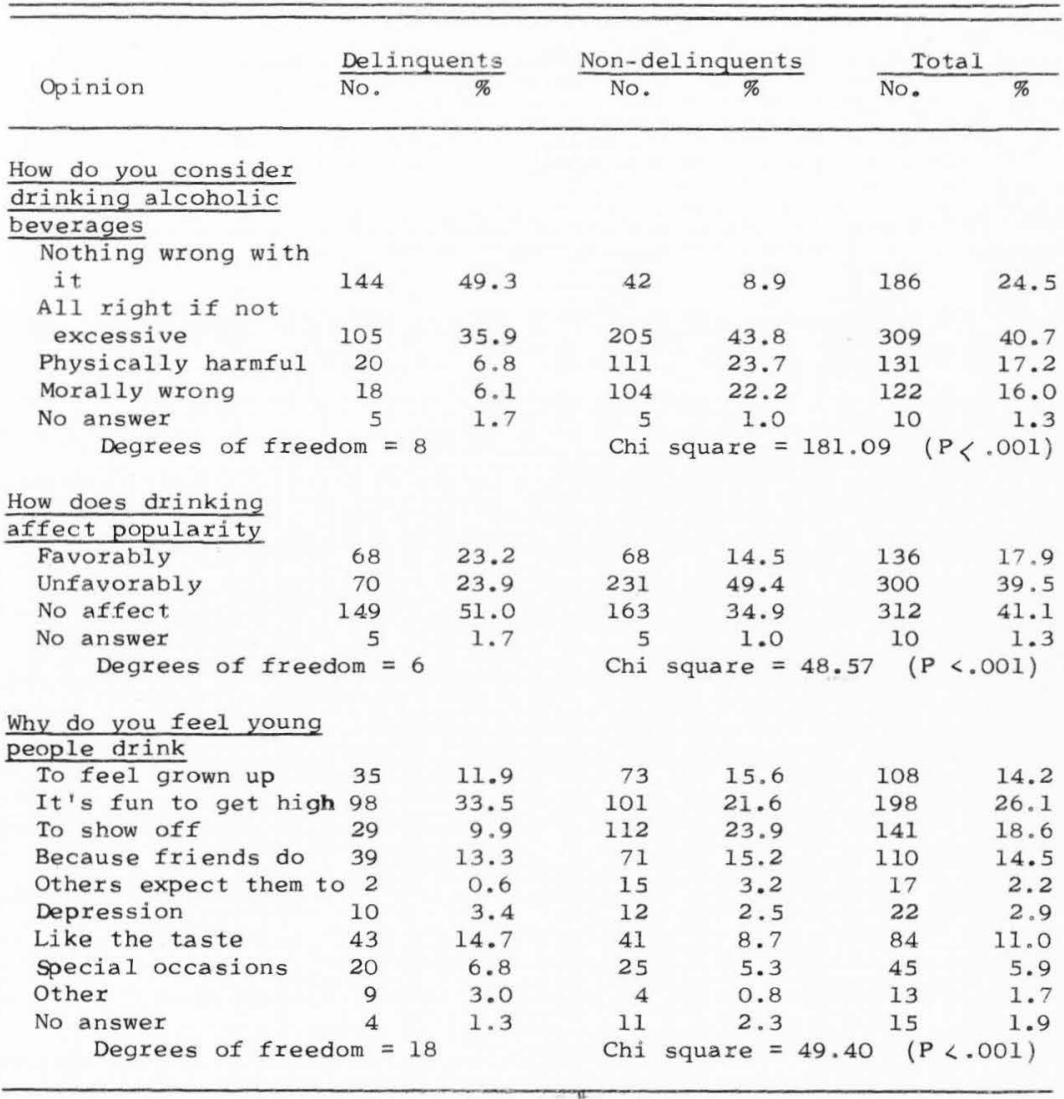


How drinking affects populasity. To the question how they felt drinking affected populstity, 136, or 17.9 per cent, stated they felt it affected popularity favorably; 300 , or 39.9 pex cent, stated they felt it affected popularity unfavorably; and 312 , or 41 per cent, stated that drinking had no affect on popularity. There were 49.3 per cent of the non-delinquents who felt that drinking affected populaxicy unfavorably, while 51.0 per cent of the delinquents felt dzinking had no affect on a persons popularity; 23.9 per cent of the delinquents felt drinking affected popularity unfavorably, and 23.2 per cent felt drinking affected popularity favorably. There were 14.5 per cent of the non-delinquents who stated that it affected it favorably, and 34.9 per cent felt it had no affect on a persons popularity. (See Table 9)

Why young people drink. To the question why they felt young people drank, 108, or 14.2 per cent, felt young people drank to feel grown up; 198, or 26.1 pex cent, said they drank because it is fun to get "high"; 141, or 18.6 per cent, said they drank to "show off"; 13, or 1.7 per cent, said they drank for other reasons not specifically listed in the questionnaire; 110 , or 14.5 per cent, said they felt young people drank because their friends did; 17 , or 2.2 per cent, said they drank because others expected them to; $22,0: 2.9$ per cent said they drank because of depression; 84, or 11.0 pez cent, said they drank because they liked the taste; and 45 , or 5.9 per cent, said they drank for special occasions. There were 33.5 per cent of the delinquents who stated they felt young people drank because it is fun to get "high." On the other hand, 
23.9 per cent of the non-delinquents felt that young people drank to show off; 21.6 per cent felt they drank becsuse it is fun to get "high"; 15.6 per cent felt they drank to feel grown up; and 15.2 per cent felt they drank because their friends did. There were 11.9 per cent of the delinquents who stated they felt young people drank to feel grown up and 13.3 per cent who felt they drank because friends did. A significant difference was found at the .001 per cent level. (See Table 9,) 


\section{CHAPTER V}

\section{ANALYSIS OF RESULTS}

In analyzing the foregoing results, profiles of the typical delinquent and non-delinquent drinker became evident.

\section{Profile of the typical delinquent juvenile drinke:}

The typical delinquent drinkex as revealed by the responses of the delinquent population of this study is one who lives with both parents, has a family income of between $\$ 6,000$ and $\$ 10,000$, and lives in an area with a population of less than 20,000 people. He is 16 years of age, and his father and mother both drink at least once a week.

The typical delinquent drinkex took his first drink between the ages of six and ten, the beverage was beer, and he did not have his parents' permission to do so. His first drink was taken at the home of a friend, and he was with one or more of his friends. His friend furnished the drink which he took "just for kicks."

He drank again in less than a week from the time of his first drink, and he usually drinks several times a week. He drinks beer which he either buys himself or which is purchased by his friends, and he generally dxinks with his boyfriends. He does, at times, drink to the point of "passing out," and there are times when he cannot remember where he has been or what he has been doing while under the influence of alcohol. The typical juvenile delinquent drinkez has not been axrested for drinking nor has he committed crimes while drinking aicohol. 
However, a high percentage (34 per cent) of his fellow delinquent drinkers has been arrested for drinking and has committed crimes while drinking alcohol.

The delinquent drinker feels there is nothing wrong with drinking aicoholic beverages and that drinking has no affect on his popularity. He believes that the young people he knows who drink, do so because they feel it is fun to get "high."

\section{Profile of a typical non-delinquent juvenile drinkex}

The typical non-delinquent user of alcohol as indicated by the responses of the population studied is one who lives with both parents. He comes from a family whose income is between $\$ 6,000$ and $\$ 10,000$, he is a high school students, and his father and mother drink once every two to five months.

He took his first drink between the ages of six and ten out of curiosity. The beverage he selected was beer which he drank with parental permission, at his own home, and in the company of parents or relatives.

He drank again within one year from the time of his first drink. He usually drinks once every two to five months, and his heaviest drinking occurs at the age of 16 . He drinks beer with either his boyfriends or his parents, but he never drinks to the point of "passing out" or not being able to remember his activities. He has never been arrested for drinking nor has he ever committed crimes while drinking aicoholic beverages.

The typical non-delinquent drinker considers drinking acceptable if not in excess, but he feels that drinking affects popularity unfavorably. He feels that young people drink to "show off" or because it is fun to get "high." 
The salient differences, therefore, in the profiles of the delinquent and non-delinquent population used in this study are: (1) the frequency with which the parents drink, (2) parental permission for drinking, (3) the place of the first drink,

(4) the frequency of drinking, and (5) what would appear to be the quantity of alcohol drunk. Also, a difference in attitude of the groups is shown in the opinions as to how drinking affects popularity and possibly value structure.

\section{Frequency of drinking compazisons}

In an effort to determine rersons for the differences found in the drinking patterns of the delinquents and the non-delinquents, the frequency of drinking was compared with selected personal.

and socio-economic factors.

Present age. In breaking the data down into the present age of the students tested versus the frequency the students drank, some interesting results were obtained. A higher percentage of the non-delinquents at all age groups stated they never drank in comparison to the number of delinquents who stated they never drank. As an example of this, there were 66.75 per cent of the non-delinquent twleve-yeasmolds who stated they never drank: 33.3 per cent of the delinquent twelve-year-olds stated they never drank. In the fifteen-yearold group, 55.5 per cent of the non-delinquents stated they never drank in comparison with only 9.3 per cent of the delinquents who never drank. In the seventeen-yeaz-old group, 44 per cent of the non-delinquents stated they never drank; and 7.25 per cent of the delinquents stated they never drank. These differences 
axe comparable at 311 ages. The age at which the heaviest drinking takes place among the delinquen ss and non-delinquents is among the sixteen-yesz-old students. Thizty-two per cent of the delinquents stated they drank several times 3 week. 15.9 per cent of the delinquents stated they drank several times a month, and 28.10 per cent of the delinquents stated they drank at least once a week. In compaxison, 5.45 per cent of the sixteen-year-old non-delinquents stated they drank several times a week, 18.10 per cent drank two ox three times a month, and only 2.7 per cent stated they drank once a month. There wexe 19.5 per cent of the sixteen-yeaz-old non-delinquents who stated they drank once every two to five months. Over 71 pex cent of the eighteen-year-old delinquents stated they drank at least once a week. In comparison, less than 23 peri cent of the non-delinquents stated they drank at least once a week. Only 6.5 per cent of the delinquent eighteen-year-olds stated they never drank compaxed with 38.5 per cent of the non-delinquents who stated they never drank.

In the age range of fifteen-year-o1ds, theze is a considerable difference between the delinquents and the non-delinquents. Thexe were only 9.3 per cent of the delinquent fifteen-year-olds who stated they did not drink in comparison with 55.5 per cent of the fifteen-year-01d non-delinquents; 55.5 pex cent of the delinquents stated they drank at least once a week in compazison with slightiy more than 10 per cent of the non-delinquent iffteen-year-olds who stated they drank at least once a week and 10 per cent who stated they drank every two to five montho which is the most frequent amount of drinking in the fifteen-yeaz-ola non-delinquent group. 
There were too few delinquents who were eleven and twelve years of age to make a compezison of theix drinking behavior. It was interesting to note that in the non-delinquent group as high as 77 per cent of the thirteen-year-olds stated they did not drink; whezeas, only 66.75 per cent of the non-delinquent: twelve-year-olds stated they did not drink.

At least half of the delinquent seventeen-yeaz-olds drank at least once a week. There were only 7.25 per cent of the delinquent seventeen-yeaz-olds who stated they did not drink. On the other hand, 44 per cent of the non-delinquent seventeenyear-olds stated they did not drink, and only 13 per cent stated they drank at least once a week. There were 5 per cent of the non-delinquents, however, who stated they drank two or three times a month and another 2 pex cent who stated they drank once every two to five months. The non-delinquent seventeenyear-olds drank less often than the delinquents seventeen-yearolds. (See Tables 10 and 11)

Sex. In comparing the frequency of drinking with the sex of the delinquent and the non-delinquent groups, some revealing results were obtained. One unexpected finding was that the female delinquents drank as frequently as the male delinquents. There were 31.1 per cent of the female delinquents who stated they drank several times a week in comparison to 32.72 per cent of the male delinquents who stated they drank several times a week. There were 22.35 per cent of the delinquent females who stated they drank at least once a week, compared to 23.37 per cent of the deilnquent males who stated they drank at least once a week. Comparing the non-delinquent males and 
Table 10. Frequency of drinking compared with present age of delinquent

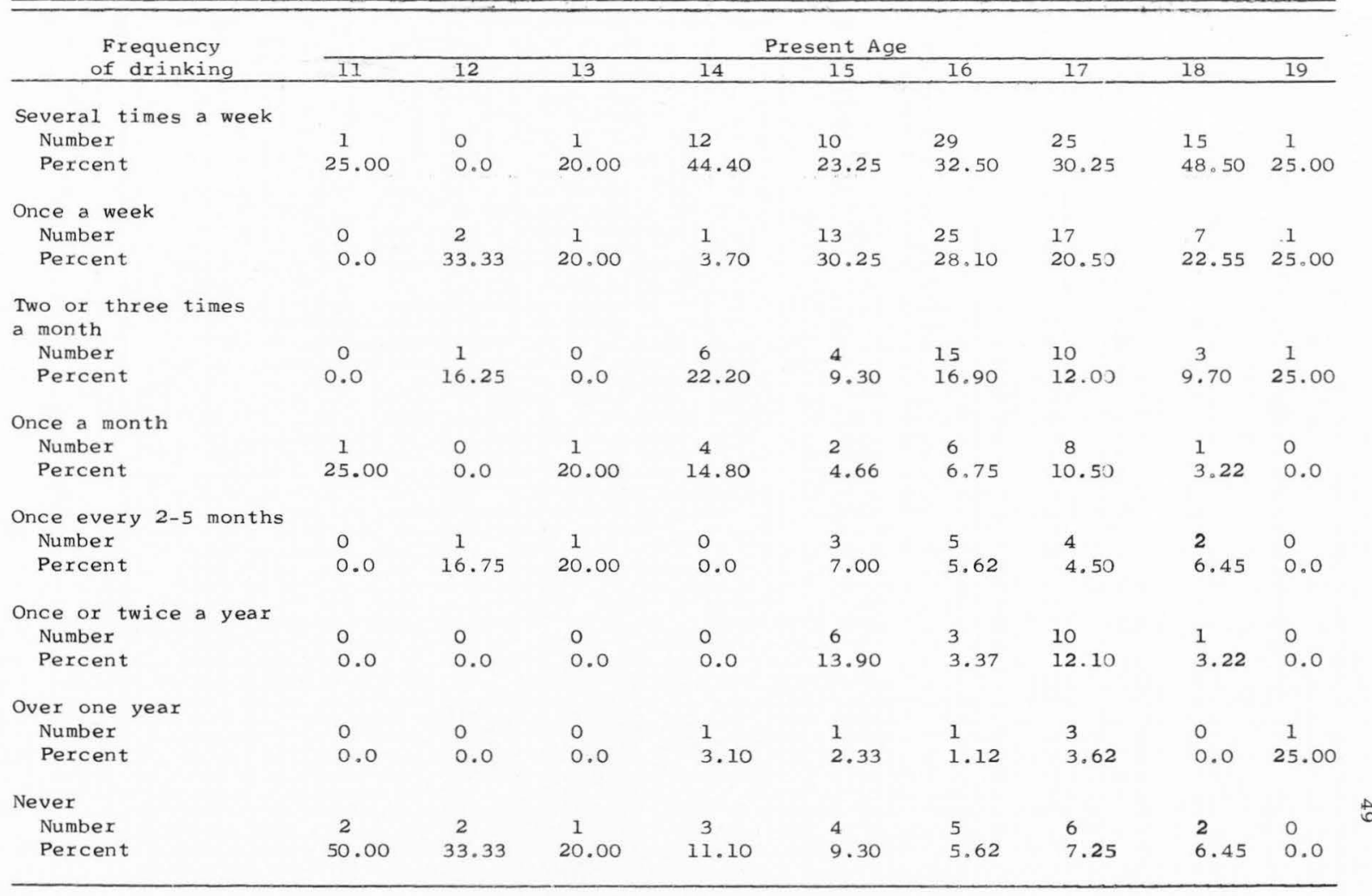


Table 11. Frequency of drinking compared with present age of non-delinquent

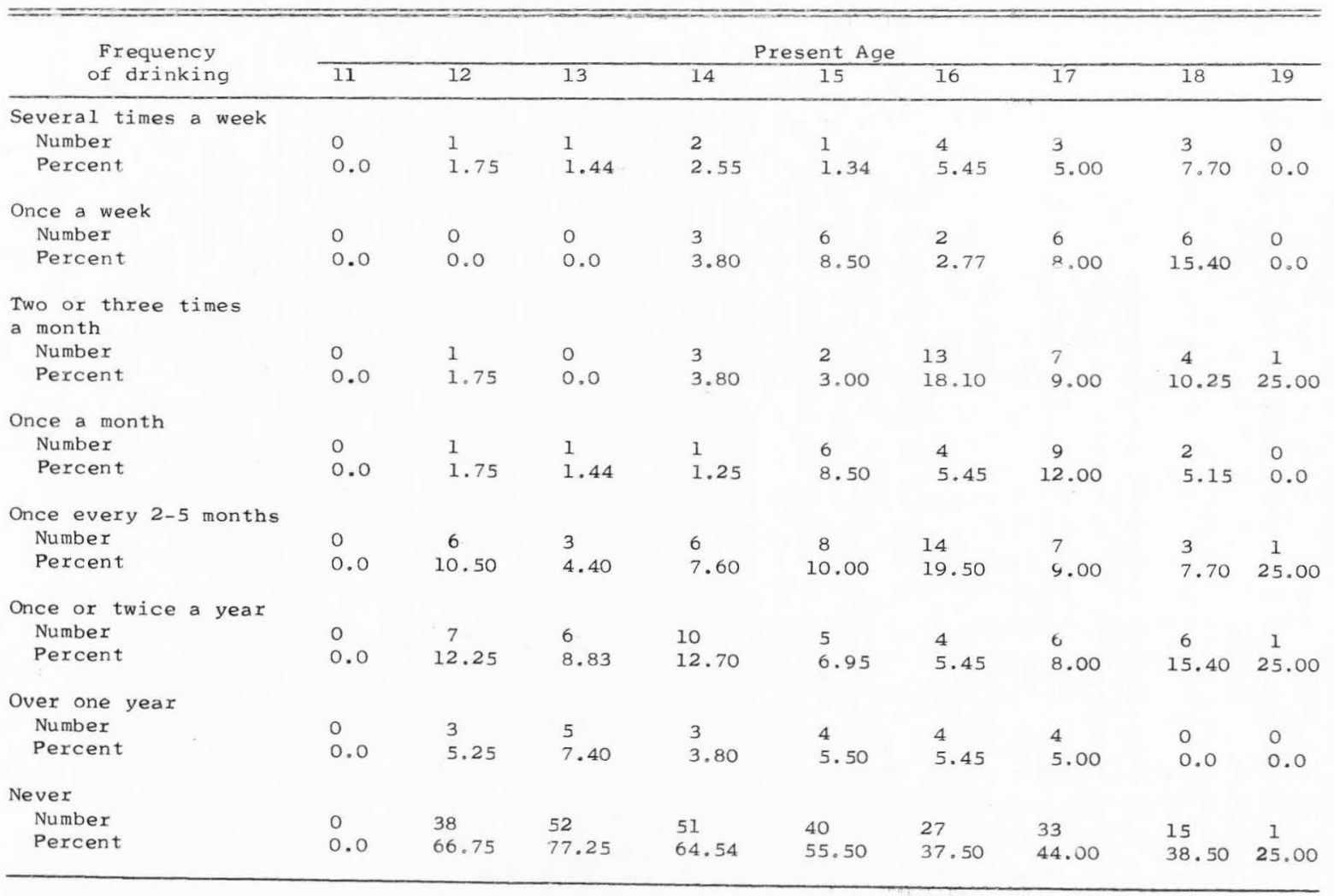


females, there was a difference in the percentage of the number of males ( 4.95 per cent) who drank several times a week and the number of females ( 1.67 per cent) who drank several times a week. There were 8.10 per cent of the males who stated they drank once a week, compared with 2.06 per cent of the females who stated they drank once a week. There were 14.41 per cent: of the non-delinquent males who stated they drank once every two to five months. There were 45.2 per cent of the nondelinquent males who stated they did not drink compared to 64.8 per cent of the non-delinquent females who stated they did not drink. In comparison, only 8.8 per cent of the delinquent males stated they did not drink: and 7.8 per cent of the delinquent females stated they did not drink.

In comparing the male delinquents with the male nondeiinquents, a difference was found in their drirking behavior. As already stated, over 50 per cent of the delinquent males drank at least once a week in comparison to only 13.5 per cent of the non-delinquent males who stated they drank at least once a week. The same differences exist between the female delinquents and the female non-delinquents. Over 50 per cent of the female delinquents drank once a week or more often, while less than 4 per cent of the non-delinquent females stated they drank once a week or more often. There is a difference also in the female non-delinquents ( 64.8 per cent) who stated they did not drink in comparison with 7.8 per cent of the female delinquents who stated they did not drink. (See Table 12)

Race. In comparing the frequency of drinking with the race of the students tested, it was found that there were too few 
Table 12. Frequency of drinking compared with sex

\begin{tabular}{|c|c|c|c|c|}
\hline \multirow{2}{*}{$\begin{array}{l}\text { Frequency } \\
\text { of drinking }\end{array}$} & \multicolumn{2}{|c|}{ Delinquents } & \multicolumn{2}{|c|}{ Non-delinquents } \\
\hline & Male & Female & Male & Female \\
\hline \multicolumn{5}{|l|}{ Several times a week } \\
\hline Number & 66 & 28 & 11 & 4 \\
\hline Percent & 32.72 & 31.10 & 4.95 & 1.64 \\
\hline \multicolumn{5}{|l|}{ Once a week } \\
\hline Number: & 47 & 20 & 18 & 5 \\
\hline Percent & 23.37 & 22.35 & 8.10 & 2.06 \\
\hline \multicolumn{5}{|l|}{$\begin{array}{l}\text { Two or three times } \\
\text { a month }\end{array}$} \\
\hline Number & 27 & 13 & 14 & 17 \\
\hline Percent & 13.49 & 14.50 & 6.31 & 7.00 \\
\hline \multicolumn{5}{|l|}{ Once a month } \\
\hline Numbex & 20 & 3 & 17 & 7 \\
\hline Percent & 9.86 & 3.34 & 7.70 & 2.87 \\
\hline \multicolumn{5}{|l|}{ Once every $2-5$ months } \\
\hline Number & 11 & 5 & 32 & 16 \\
\hline Percent & 5.45 & 5.56 & 14.41 & 6.60 \\
\hline \multicolumn{5}{|l|}{ Once or twice a year } \\
\hline Number & 9 & 11 & 21 & 24 \\
\hline Percent & 4.47 & 12.40 & 9.49 & 9.90 \\
\hline \multicolumn{5}{|l|}{ Over one year } \\
\hline Number & 4 & 3 & 9 & 14 \\
\hline Percent & 1.98 & 3.34 & 4.05 & 5.78 \\
\hline \multicolumn{5}{|l|}{ Never } \\
\hline Number & 18 & $?$ & 100 & 157 \\
\hline Percent & 8.98 & 7.80 & 45.20 & 64.80 \\
\hline
\end{tabular}


Negroes and Orientals in the delinquent and non-delinquent groups to make a comparison. There were also too few Indians and Mexicans in the non-delinquent group to make a comparison. Of the 213 delinquent Caucasians tested, 31.52 pez cent of them stated they drank several times a week. Anothe: 23.55 per cent stated they drank at least once a week. Only 8.48 pez cent stated they did not drink. In compacison, 56 per cent of the 450 non-delinquent Caucasians tested stated they did not drink. Only 3.11 per cent stated they drank several tilmes a week, and only 4.9 per cent stated they drank once a week.

Of the 35 Indians in the delinquent group, 25.7 per cent stated they drank several times a week, with 20 per cent stating they drank at least once a week and another 20 per cent stating they drank two or three times a month. Only 5.72 per cent stated they did not drink. (See Tables 13 and 14)

Family income. Very little difference was found among the delinquents as far as income versus frequency of drinking; but there was a difference in the non-delinquent group regarding income and frequency of drinking. Of the delinquents who stated their family income was under $\$ 3,000,29.6$ per cent stated they drank several times a week, 20.4 per cent drank two or three times a month, and 22.3 per cent drank at least once a week. In comparing the under $\$ 3,000$ income group with the $\$ 3,000-\$ 5,999$ income group, 27.45 per cent stated they drank several times a week, 28.55 per cent stated they drank at least once a week, and 14.3 pez cent stated they drank two or three times a month. In the $\$ 6,000-\$ 10,000$ income group, 32.5 per cent stated they drank several times a 
Table 13. Frequency of delinquent's drinking compared with race

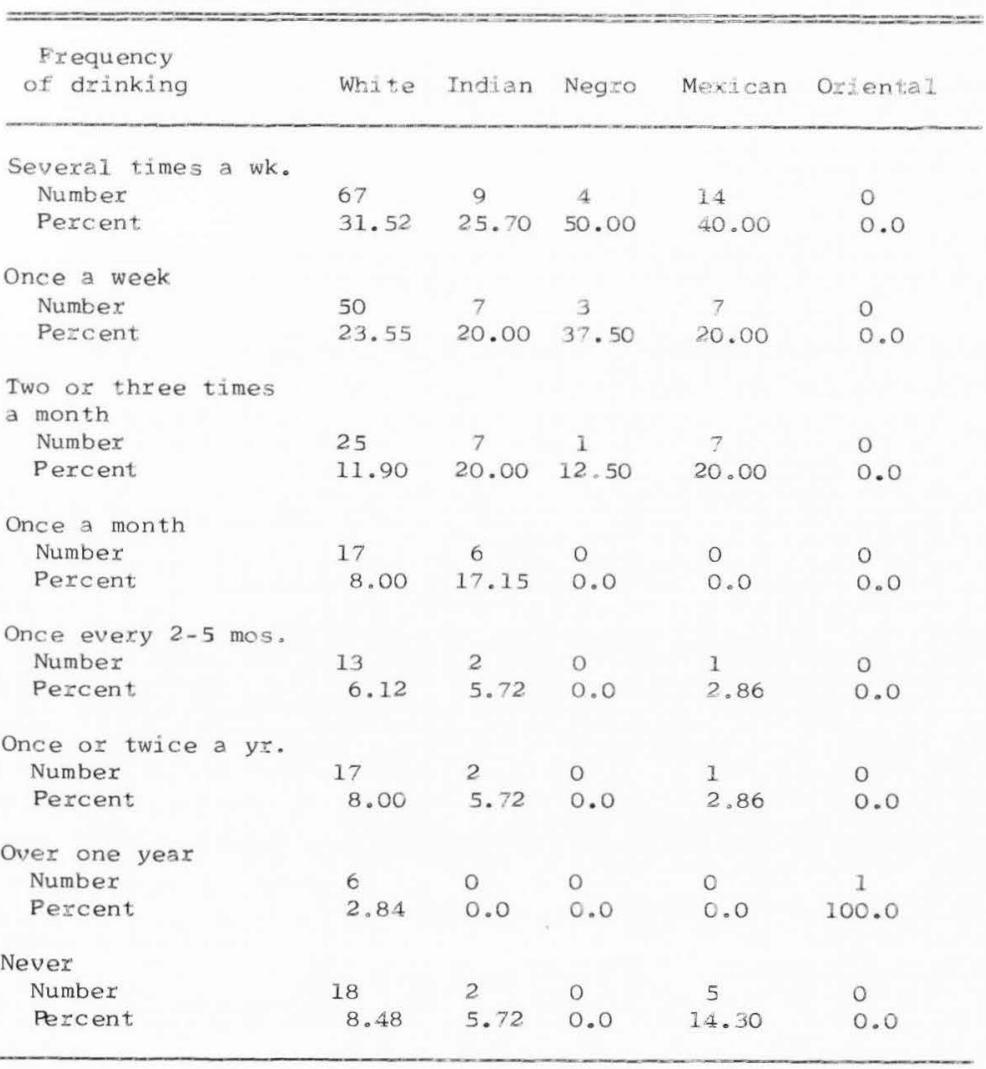


Table 14. Frequency of non-delinquent's drinking compared with race

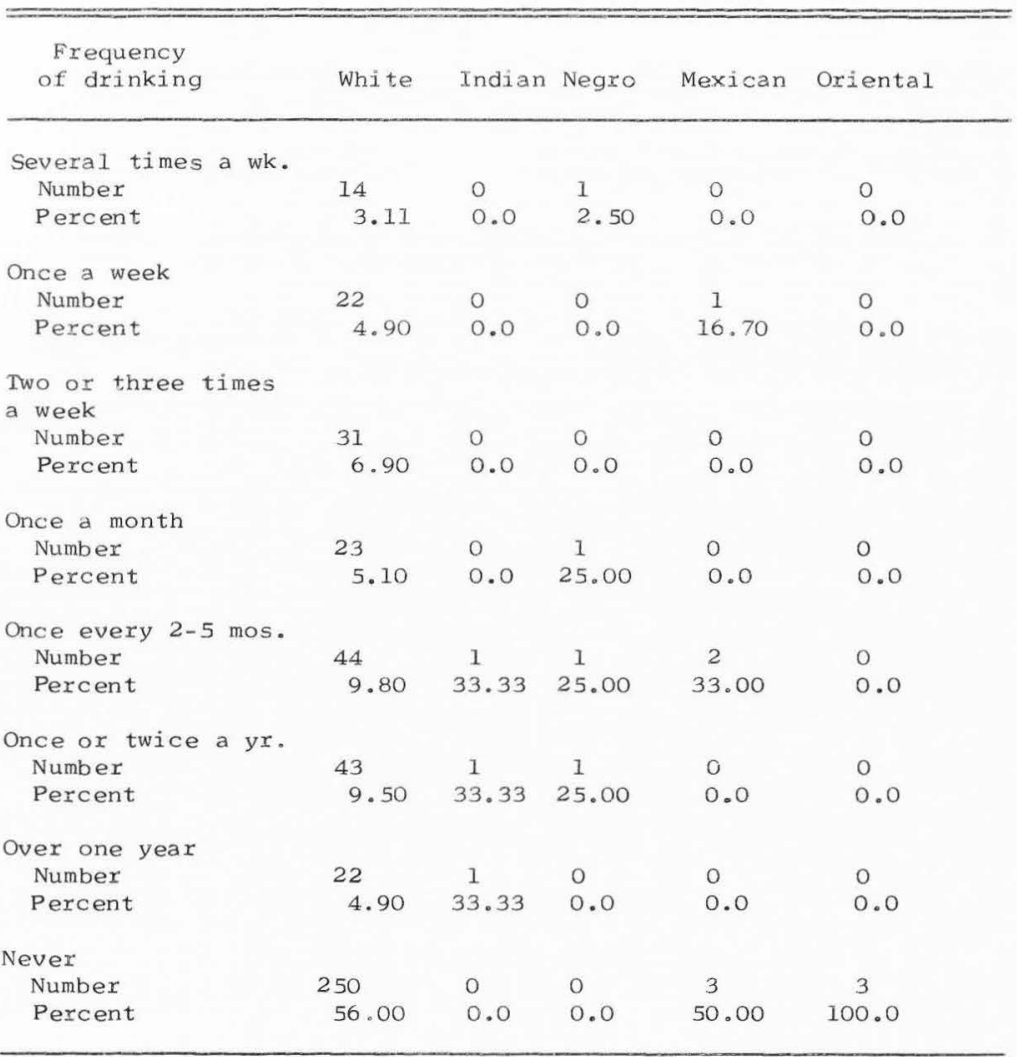


week, 15 per cent drank two or three times a month, and 21.25

per cent drank once a week. Of the students stating their family

income was over $\$ 10,000,37.5$ per cent stated they drank

several times a week, 20 per cent drank once a week, and only

8.9 per cent drank two ox three times a month. There was

little variation in the number of students in each of these

groups who stated they never drink. The percentage of delinquents

reporting they did not drink was 11.10 per cent in the under

$\$ 3,000$ income group, 7.15 per cent in the $\$ 3,000-\$ 5,999$ income

group, 10.10 per cent in the $\$ 6,000-\$ 10,000$ income group,

and 6.6 per cent in the over $\$ 10,000$ income group.

Little variation was found among the income groups as far as the frequency of drinking of the non-delinquents. Eleven per cent of the non-delinquents in the $\$ 6,000-\$ 10,000$ income group drank every two to five months. This was the highest percentage in any of the groups for any of the frequencies. There were 70.10 per cent of the non-delinquents in the under $\$ 3,000$ income group who stated they never drink, 58 per cent in the $\$ 3,000-\$ 5,999$ income group never drink, 55.8 pex cent in the $\$ 6,000-\$ 10,000$ income group never dxink, and 45.9 per cent in the over $\$ 10,000$ income group never drink. There were only 6.46 per cent of those in the under $\$ 3,000$ income group who drank once or more times a week in comparison to 14.8 per cent of those with family incomes of above $\$ 10,000$ who stated they drank at least once a week. (See Table 15)

Area lived in. The frequency of drinking was compared with the population of the area in which the delinquents and non-delinquents lived. There was little variation among the 
Table 15. Frequency of drinking compared with family income

\begin{tabular}{|c|c|c|c|c|c|c|c|c|}
\hline \multirow[b]{2}{*}{$\begin{array}{l}\text { Frequency } \\
\text { of drinking }\end{array}$} & \multicolumn{4}{|c|}{ Delinguents } & \multicolumn{4}{|c|}{ Non-delinquents } \\
\hline & $\begin{array}{l}\text { Under } \\
\$ 3,000\end{array}$ & $\begin{array}{l}\$ 3,000- \\
5,999\end{array}$ & $\begin{array}{l}\$ 6,000 \\
10,000\end{array}$ & $\begin{array}{c}\text { Over } \\
\$ 10,000\end{array}$ & $\begin{array}{r}\text { Under } \\
\$ 3,000\end{array}$ & $\begin{array}{c}\$ 3,000- \\
5,999\end{array}$ & $\begin{array}{l}\$ 6,000- \\
10,000\end{array}$ & $\begin{array}{c}\text { Ovex } \\
\$ 10,000\end{array}$ \\
\hline \multicolumn{9}{|l|}{ Several times a week } \\
\hline Number & 16 & 23 & 26 & 17 & 1 & 3 & 4 & 6 \\
\hline Percent & 29.60 & 27.45 & 32.50 & 37.50 & 3.23 & 3.40 & 1.80 & 5.90 \\
\hline \multicolumn{9}{|l|}{ Once a week } \\
\hline Number & 12 & 24 & 17 & 9 & 1 & 3 & 10 & 9 \\
\hline Percent & 22.30 & 28.55 & 21.25 & 20.00 & 3.23 & 3.40 & 4.50 & 8.90 \\
\hline \multicolumn{9}{|l|}{$\begin{array}{l}\text { Two or three times } \\
\text { a month }\end{array}$} \\
\hline Numbex & 11 & 12 & 12 & 4 & 0 & 5 & 17 & 8 \\
\hline Percent & 20.40 & 14.30 & 15.00 & 8.90 & 0.0 & 5.70 & 7.60 & 7.90 \\
\hline \multicolumn{9}{|l|}{ Once a month } \\
\hline Number & I & 10 & 5 & 3 & 2 & 2 & 17 & 2 \\
\hline Percent & 1.86 & 11.90 & 6.25 & 6.66 & 6.45 & 2.38 & 7.60 & 1.90 \\
\hline \multicolumn{9}{|c|}{ Once every $2-5$ months } \\
\hline Number & 4 & 4 & 4 & 2 & 1 & 8 & 25 & 11 \\
\hline Percent & 7.44 & 4.76 & 5.00 & 4.45 & 3.23 & 9.10 & 11.20 & 10.90 \\
\hline \multicolumn{9}{|c|}{ Once or twice a year } \\
\hline Number & 3 & 3 & 7 & 5 & 3 & 13 & 18 & 1.1 \\
\hline Percent & 5.55 & 3.58 & 8.75 & 11.05 & 9.70 & 14.80 & 8.10 & 10.90 \\
\hline \multicolumn{9}{|l|}{ Over one year } \\
\hline Number & 1 & 2 & 1 & 2 & 1 & 3 & 9 & 8 \\
\hline Percent & 1.86 & 2.38 & 1.25 & 4.45 & 3.23 & 3.40 & 4.05 & 7.90 \\
\hline \multicolumn{9}{|l|}{ Never } \\
\hline Number & 6 & 6 & 8 & 3 & 22 & 51 & 124 & 46 \\
\hline Percent & 11.10 & 7.15 & 10.00 & 6.66 & 70.10 & 58.00 & 55.80 & 45.90 \\
\hline
\end{tabular}


delinquents who lived in an area of 8,000 in population:

those who lived in an area of 20,000 in populat.on, and those who lived in an area of over 20,000 in population. The same applies to the non-delinquent groups. There was a variation betweren the delinquents who lived in an area under 8,000 in population and the non-delinquents who lived in an area under 8,000 in population. Thirty per cent of the delinquents who lived in an area under 8,000 in population stated they drank several times a week, while only 2.45 per cent of the non-delinquents who lived in an area under 8,000 in population stated they drank several times a week. The same ratio applies to delinquents living in areas of 8,000 to 20,000 in population and the nondelinquents who also lived in areas of 8,000 to 20,000 people. It also applies to those delinquents who lived in areas above 20,000 in population in comparison to the non-delinquents who lived in areas above 20,000 in population. There was a difference in the percentage of non-delinquents living in areas under 8,000 who did not drink (61 per cent) in comparison to 7.23 per cent of the delinquents living in areas under 8,000 in population who stated they did not drink. The same ratio again applies to the delinquents and the non-delinquents in the other groupings. (See Table 16)

With whom the students lived. In comparing the question with whom the students lived with the frequency of drinking, there were too few non-delinquents living with theil father only ox living with neither their father nor their mother to make a comparison of the two groups. Of those living with their father only, 47.5 per cent stated they drank several times 
Table 16. Frequency of drinking compared with population of area lived in

\begin{tabular}{|c|c|c|c|c|c|c|}
\hline \multirow[b]{2}{*}{$\begin{array}{l}\text { Frequency } \\
\text { of drinking }\end{array}$} & \multicolumn{3}{|c|}{ Delinquents } & \multicolumn{3}{|c|}{ Non-delinquents } \\
\hline & $\begin{array}{l}\text { Under } \\
8,000\end{array}$ & $\begin{array}{l}8,000- \\
20,000\end{array}$ & $\begin{array}{l}\text { Above } \\
20,000\end{array}$ & $\begin{array}{l}\text { Undex } \\
8,000\end{array}$ & $\begin{array}{l}8,000- \\
20,000\end{array}$ & $\begin{array}{l}\text { Above } \\
20,000\end{array}$ \\
\hline \multicolumn{7}{|l|}{ Several times a week } \\
\hline Number & 33 & 19 & 37 & 1 & 4 & 10 \\
\hline Percent & 30.00 & 30.50 & 34.00 & 2.45 & 5.20 & 2.90 \\
\hline \multicolumn{7}{|l|}{ Once a week } \\
\hline Number & 26 & 12 & 25 & 2 & 3 & 18 \\
\hline Percent & 23.75 & 19.40 & 23.00 & 4.85 & 3.80 & 5.20 \\
\hline \multicolumn{7}{|l|}{$\begin{array}{l}\text { Two or three times } \\
\text { a month }\end{array}$} \\
\hline Number & 20 & 7 & 13 & 1 & 7 & 23 \\
\hline Percent & 18.15 & 11.30 & 11.95 & 2.45 & 9.10 & 6.61 \\
\hline \multicolumn{7}{|l|}{ Once a month } \\
\hline Number & 12 & 5 & 6 & 2 & 5 & 17 \\
\hline Percent & 10.09 & 8.10 & 5.50 & 4.85 & 6.50 & 4.90 \\
\hline \multicolumn{7}{|l|}{ Once every 2-5 months } \\
\hline Number & 4 & 4 & 8 & 3 & 7 & 38 \\
\hline Percent & 3.63 & 6.45 & 7.31 & 7.31 & 9.10 & 10.62 \\
\hline \multicolumn{7}{|l|}{ Once or twice a year: } \\
\hline Number & 6 & 6 & 7 & 5 & 7 & 33 \\
\hline Percent & 5.45 & 9.70 & 6.41 & 12.20 & 9.10 & 9.50 \\
\hline \multicolumn{7}{|l|}{ Over one year } \\
\hline Number & 1 & 2 & 4 & 2 & 4 & 17 \\
\hline Pexcent & 0.91 & 3.27 & 3.68 & 4.85 & 5.20 & 4.90 \\
\hline \multicolumn{7}{|l|}{ Never } \\
\hline Number & 8 & 7 & 9 & 25 & 40 & 192 \\
\hline Percent & 7.30 & 11.30 & 8.25 & 61.00 & 52.00 & 55.50 \\
\hline
\end{tabular}


a week, another 21 per cent stated they drank once a week, and 10 per cent drank two or three times a month. No students living with their father only reported they did not drink. Of the delinquent students reporting they lived with their mothex only, 30.25 per cent drank several times a week, 16.25 per cent drank two or three times a month, and 28.75 per cent drank once a week. In comparing this group with the non-delinquent group who lived with their mother on $1 y$, 10.5 per cent stated they drank several times a week, 4.18 per cent drank once a week, and only 6.25 per cent drank two or three times a month. There were 54.25 per cent of the non-delinquents who lived with their mother only who stated they did not drink, in comparison to only 8.25 per cent of the delinquents who stated they lived with theix mother only. There were over 50 per cent of the delinquents who lived with both parents who drank at: least once a week, in comparison to only 6.75 per cent of the non-delinquents who lived with both parents who drank that often. There were 55.75 per cent of the non-delinquents who stated they did not drink in comparison to only 10.20 per cent of the delinquents who did not drink who lived with both parents. (See Table 17)

Father's drinking behavior. In regards to the drinking behavior of the father versus the frequency of the delinquent student's drinking, 45.42 per cent reporting their fathers never drank stated they drank at least once a week. In comparison, of those delinquent students reporting their fathers drank once a week, 71.75 per cent stated they drank at least once a week. Of the delinquent students stating their 
Tabie 17. Frequency of drinking compared with whom the students Iived

\begin{tabular}{|c|c|c|c|c|c|c|c|c|}
\hline \multirow[b]{2}{*}{$\begin{array}{l}\text { Frequency } \\
\text { of drinking }\end{array}$} & \multicolumn{4}{|c|}{ Delinquents } & \multicolumn{4}{|c|}{ Non-Delinquents } \\
\hline & $\begin{array}{l}\text { Both } \\
\text { Parents }\end{array}$ & $\begin{array}{l}\text { Father } \\
\text { Only }\end{array}$ & $\begin{array}{l}\text { Mother } \\
\text { Only }\end{array}$ & Neithex & $\begin{array}{l}\text { Both } \\
\text { Parents }\end{array}$ & $\begin{array}{c}\text { Father } \\
\text { Only }\end{array}$ & $\begin{array}{c}\text { Mother } \\
\text { Only }\end{array}$ & Nei thex \\
\hline \multicolumn{9}{|l|}{ Several times a week } \\
\hline Number & 48 & 9 & 22 & 15 & 7 & 1 & 5 & 2 \\
\hline Pexcent & 30.50 & 47.50 & 30.25 & 35.75 & 1.75 & 14.15 & 10.50 & 18.20 \\
\hline \multicolumn{9}{|l|}{ Once a week } \\
\hline Number & 31 & 4 & 21 & 11 & 20 & 0 & 2 & 1 \\
\hline Pexcent & 19.70 & 21.00 & 28.75 & 26.25 & 5.00 & 0.0 & 4.18 & 9.10 \\
\hline \multicolumn{9}{|l|}{$\begin{array}{l}\text { Two ox three times } \\
\text { a month }\end{array}$} \\
\hline Number & 22 & 2 & 12 & 4 & 27 & $\mathrm{o}$ & 3 & 1 \\
\hline Pexcent & 14.00 & 10.50 & 16.25 & 9.90 & 6.75 & 0.0 & 6.25 & 9.10 \\
\hline \multicolumn{9}{|l|}{ Once a month } \\
\hline Number & 15 & 2 & 5 & 1 & 19 & 0 & 3 & 2 \\
\hline Percent & 9.55 & 10.50 & 6.85 & 2.40 & 4.75 & 0.0 & 6.25 & 18.20 \\
\hline \multicolumn{9}{|l|}{ Once every $2-5$ months } \\
\hline Number & 11 & 0 & 3 & 1 & 40 & 1 & 6 & 1 \\
\hline Percent & 7.00 & 0.0 & 4.10 & 2.40 & 10.00 & 14.15 & 12.50 & 9.10 \\
\hline \multicolumn{9}{|l|}{ Once ox twice a year } \\
\hline Number & 12 & 2 & 4 & 2 & 42 & 0 & 3 & 0 \\
\hline Percent & 7.65 & 10.50 & 5.50 & 4.75 & 10.50 & 0.0 & 6.25 & 0.0 \\
\hline \multicolumn{9}{|l|}{ Over one year } \\
\hline Number & 2 & 0 & 0 & 5 & 23 & 0 & 0 & 0 \\
\hline Percent & 1.27 & 0.0 & 0.0 & 11.95 & 5.75 & 0.0 & 0.0 & 0.0 \\
\hline \multicolumn{9}{|l|}{ Never } \\
\hline Number & 16 & 0 & 6 & 3 & 222 & 5 & 26 & 4 \\
\hline Pexcent & 10.20 & 0.0 & 8.25 & 7.15 & 55.75 & 71.50 & 54.25 & 36.25 \\
\hline
\end{tabular}


fathers drank every day, 69 per cent stated they drank at least once a week or more often. There were too few nondelinquent students reporting in each of the categories to make a comparison. There were enough to make a comparison with those students who never drank and the drinking behavior of theix parents. There were 82 per cent of the non-delinquent students who stated thei I fathers never drank who dad not drink themselves, with 30.5 per cent of those who stated their fathers drank once a week who did not drink. There were 31.25 per cent whose fathers drank several times a week who did not drink, and 25.75 per cent whose fathers drank every day who did not drink. In comparing this with the delinquent group who stated they did not drink, 15.3 per cent of the delinquents whose fathers did not drink, did not dránk; 3.4 per cent whose fathers drank several times a week did not drink; and 6.9 per cent of whose fathers drank every day did not drink. There were no students whose fathers drank once a week reporting that they did not drink. (See Tables 18 and 19)

\section{Mother's drinking behavior. In comparing the drinking} behavior of the mothers with the frequency of drinking of the students tested, it was found that there were too few nondelinquents in the various categories to warrant reporting the results. Of the delinquents reporting their mothers never drank, 32 per cent stated they drank several times a week, 21.5 per cent reported they drank once a week, and 11 per cent reported they drank two or three times a month. Of those reporting their mothers drank at 1 east once a week, 46.75 per cent stated they drank several times a week; and 26.75 per cent drank once a week. There were 33.3 per cent of the delinquents 
Table 18. Frequency of delinquent's drinking compared with father's dxinking behavior

\begin{tabular}{|c|c|c|c|c|c|c|c|c|}
\hline $\begin{array}{l}\text { Frequency } \\
\text { of drinking }\end{array}$ & Never & $\begin{array}{c}\text { Once or } \\
\text { twice } \\
\text { a year }\end{array}$ & $\begin{array}{l}\text { Once } \\
\text { every } \\
2-5 \text { mos. }\end{array}$ & $\begin{array}{l}\text { Once } \\
\text { a } \\
\text { month }\end{array}$ & $\begin{array}{c}2-3 \\
\text { times } \\
\text { a mo. }\end{array}$ & $\begin{array}{c}\text { Once } \\
\text { a } \\
\text { week }\end{array}$ & $\begin{array}{c}\text { Several } \\
\text { times } \\
\text { a week }\end{array}$ & $\begin{array}{l}\text { Every } \\
\text { day }\end{array}$ \\
\hline \multicolumn{9}{|c|}{ Several times a week } \\
\hline Number & 22 & 9 & 6 & 6 & 6 & 12 & 13. & 12 \\
\hline Pexcent & 30.10 & 27.25 & $37 \cdot 50$ & 28.50 & 21.50 & 43.00 & 39.50 & 41.50 \\
\hline \multicolumn{9}{|l|}{ Once a week } \\
\hline Number. & 11 & 9 & 1 & 5 & 8 & 8 & 8 & 8 \\
\hline Percent & 15.30 & 27.25 & 6.25 & 23.75 & 28.75 & 28.75 & 24.25 & $27 \cdot 50$ \\
\hline \multicolumn{9}{|l|}{$\begin{array}{l}\text { Two or three times } \\
\text { a month }\end{array}$} \\
\hline Number & 9 & 5 & 2 & 4 & 5 & 2 & 4 & 2 \\
\hline Percent & 12.50 & 15.20 & 12.50 & 19.00 & 17.80 & 7.15 & 12.15 & 6.90 \\
\hline \multicolumn{9}{|l|}{ Once a month } \\
\hline Number & 5 & 1 & 2 & 2 & 4 & 2 & 2 & 2 \\
\hline Percent & 6.95 & 3.40 & $12 \cdot 50$ & 9.50 & 14.25 & 6.15 & 6.80 & 6.90 \\
\hline \multicolumn{9}{|c|}{ Once every $2-5$ months } \\
\hline Number & 6 & 1 & 0 & 1 & 2 & 2 & 1 & 2 \\
\hline Percent & 8.35 & 3.40 & 0.0 & 4.75 & 7.15 & 6.15 & 3.40 & 6.90 \\
\hline \multicolumn{9}{|l|}{ Once or twice a year } \\
\hline Number & 6 & 4 & 1 & 0 & 3 & 1 & 3 & 1 \\
\hline Percent & 8.35 & 12.15 & 6.25 & 0.0 & 10.75 & 3.60 & 9.10 & 3.45 \\
\hline \multicolumn{9}{|l|}{ Over one year } \\
\hline Number & 2 & 1 & 1 & 0 & 0 & 1 & 1 & 0 \\
\hline Percent & 2.80 & 3.40 & 6.25 & 0.0 & 0.0 & 3.60 & 3.40 & 0.0 \\
\hline \multicolumn{9}{|l|}{ Never } \\
\hline Number & 11 & 3 & 3 & 3 & 0 & 0 & 1 & 2 \\
\hline Percent & 15.30 & 9.10 & 18.75 & 14.25 & 0.0 & 0.0 & 3.40 & 6.90 \\
\hline
\end{tabular}


Table 19. Frequency of non-delinquent's drinking compared with father's ditinking hehavior

\begin{tabular}{|c|c|c|c|c|c|c|c|c|}
\hline $\begin{array}{l}\text { Frequency } \\
\text { of drinking }\end{array}$ & Never & $\begin{array}{l}\text { Once or } \\
\text { twice } \\
\text { a year }\end{array}$ & $\begin{array}{l}\text { Once } \\
\text { every } \\
2-5 \text { mos. }\end{array}$ & $\begin{array}{l}\text { Once } \\
\text { a } \\
\text { month }\end{array}$ & $\begin{array}{l}2-3 \\
\text { times } \\
\text { a mo. }\end{array}$ & $\begin{array}{c}\text { Once } \\
\text { a } \\
\text { week }\end{array}$ & $\begin{array}{c}\text { Several } \\
\text { times } \\
\text { a week }\end{array}$ & $\begin{array}{l}\text { Every } \\
\text { day }\end{array}$ \\
\hline \multicolumn{9}{|c|}{ Several times a week } \\
\hline Number & 2 & 2 & 0 & 0 & 1 & 1 & 3 & 3 \\
\hline Percent & 1.25 & 3.25 & 0.0 & 0.0 & 3.35 & 2.75 & 6.66 & 9.70 \\
\hline \multicolumn{9}{|l|}{ Once a week } \\
\hline Number & 4 & 1 & 2 & 2 & 2 & 3 & 7 & 1 \\
\hline Percent & 2,42 & 1.62 & 4.35 & 7.15 & 6.70 & 8.35 & 15.50 & 3.25 \\
\hline \multicolumn{9}{|l|}{$\begin{array}{l}\text { Two or three times } \\
\text { a month }\end{array}$} \\
\hline Number & 3 & 3 & 4 & 3 & 1 & 3 & 6 & 6 \\
\hline Percent & 2.00 & 4.85 & 8.70 & 10.75 & 3.35 & 8.55 & 13.30 & 19.40 \\
\hline \multicolumn{9}{|l|}{ Once a month } \\
\hline Number & 1 & 6 & 3 & 2 & 0 & 3 & 2 & 6 \\
\hline Percent & 0.61 & 9.70 & 6.50 & 7.15 & 0.0 & 8.35 & 4.45 & 19.40 \\
\hline \multicolumn{9}{|c|}{ Once every $2-5$ months } \\
\hline Number & 9 & 7 & 2 & 5 & 3 & 8 & 8 & 2 \\
\hline Percent & 6.00 & 11.20 & 4.35 & $17 \cdot 90$ & 10.00 & 22.25 & 17.75 & 6.45 \\
\hline \multicolumn{9}{|c|}{ Once or twice a year } \\
\hline Number & 4 & 13 & 10 & 2 & 4 & 4 & 3 & 5 \\
\hline Percent & 2.42 & 21.00 & 21.75 & 7.15 & 13.25 & 11.10 & 6.66 & 16.15 \\
\hline \multicolumn{9}{|l|}{ Over one year } \\
\hline Number & 7 & 1 & 3 & 2 & 4 & 3 & 3 & 0 \\
\hline Percent & 4.25 & 1.62 & 6.50 & 7.15 & 13.25 & 8.35 & 6.66 & 0.0 \\
\hline \multicolumn{9}{|l|}{ Never } \\
\hline Number & 135 & 29 & 22 & 12 & 15 & 11 & 14 & 8 \\
\hline Percent & 82.00 & 47.00 & 47.75 & 43.00 & 50.00 & 30.50 & 31.25 & 25.75 \\
\hline
\end{tabular}


who reported their mothers drank several times a week who also drank several times a week; 22.25 per cent drank once a week; and 16.6 per cent drank two or three times a month. Of those reporting their mothers drank every day, 44.5 per cent reported they drank several times a week, 11.15 per cent drank two or three times a month, and 38 per cent drank once a week. In the non-delinquent group, 75.5 per cent of those who stated their mothers did not drink, did not drink themselves; and 45.5 per cent of those whose mothers drank two or three times a month reported they did not drink. Of those whose mothers drank once a week, 27.5 per cent reported they did not drink; and of those whose mothers drank several times a week, 19.4 per cent did not drink. Twenty-two per cent of those whose mothers drank every day did not drink. In compaxison, only 11.9 per cent of the delinquents who stated theix mothers did not drank reported that they did not drink; 6.68 per cent of those whose mothers drank once a week $x$ eported they did not drink; and 5.55 per cent of those whose mothers drank every day reported they did not drink. (See Tables 20 and 21) Attitudes toward drinking. The attitudes of both the delinquents and the non-delinquents seemed to correlate directly with the frequency of the students' drinking habits. A high percentage of the delinquents and non-delinquents who drank frequently felt there was nothing wrong with it or that it was all right to drink if not in excess. Of the delinquents and non-delinquents who did not drink, a high percentage felt it was physically harmful or morally wrong to drink. (See Tables 22 and 23) 
Table 20. Frequency of delinquent's dxinking compared with mother's drinking behavior

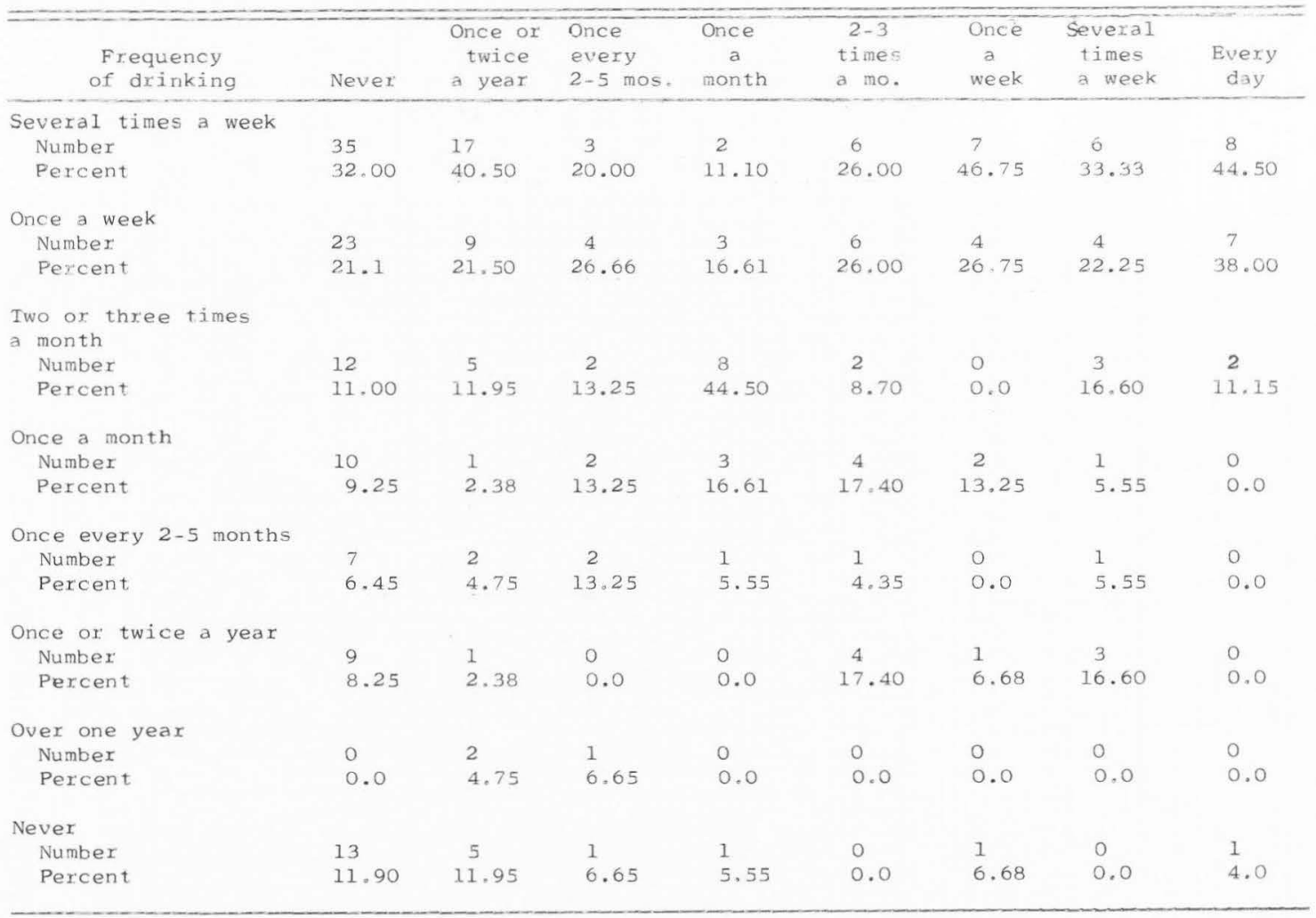


Table 2l. Frequency of non-delinquent's dxinking compared with mother's drinking behavior

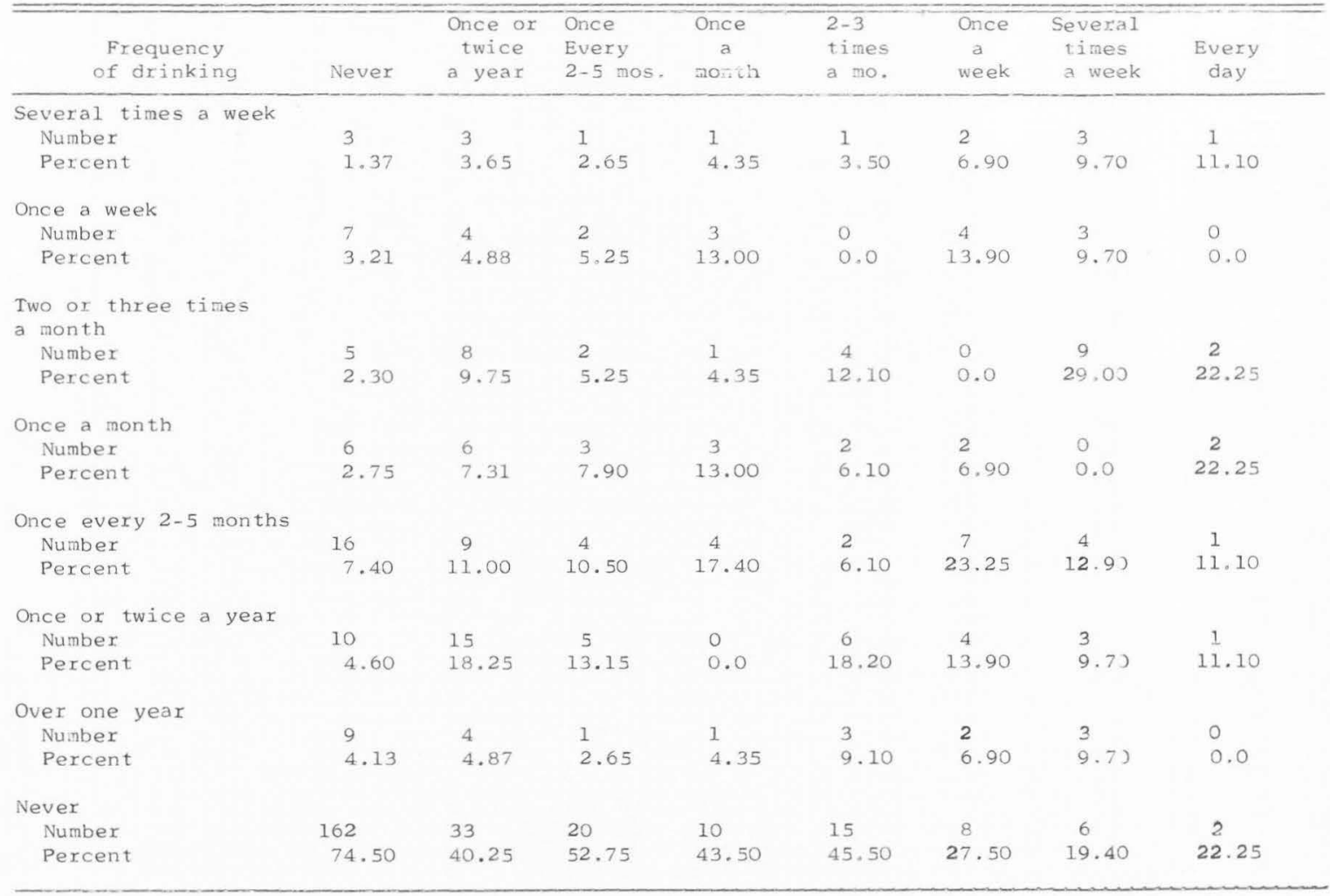


Table 22. Frequency of delinquent's drinking compared with attitude toward drinking

\begin{tabular}{|c|c|c|c|c|}
\hline $\begin{array}{l}\text { Frequency } \\
\text { of drinking }\end{array}$ & $\begin{array}{l}\text { Nothing } \\
\text { wrong }\end{array}$ & $\begin{array}{l}\text { All right } \\
\text { if not } \\
\text { excessive }\end{array}$ & $\begin{array}{c}\text { Physically } \\
\text { Harmful }\end{array}$ & $\begin{array}{c}\text { Morally } \\
\text { wrong }\end{array}$ \\
\hline \multicolumn{5}{|l|}{ Several times a week } \\
\hline Number & 60 & 27 & 3 & 4 \\
\hline Percent & 41.50 & 25.75 & 15.00 & 22.25 \\
\hline \multicolumn{5}{|l|}{ Once a week } \\
\hline Number & 42 & 19 & 5 & 0 \\
\hline Percent & 29.25 & 18.00 & 25.00 & 0.0 \\
\hline \multicolumn{5}{|l|}{$\begin{array}{l}\text { Two or three times } \\
\text { a month }\end{array}$} \\
\hline Numbex & 19 & 17 & 1 & 2 \\
\hline Percent & 13.20 & 16.20 & 5.00 & 11.25 \\
\hline \multicolumn{5}{|l|}{ Once a month } \\
\hline Number & 7 & 14 & 1 & 1 \\
\hline Percent & 4.80 & 13.30 & 5.00 & 5.55 \\
\hline \multicolumn{5}{|l|}{ Once every $2-5$ months } \\
\hline Number & 7 & 5 & 2 & 2 \\
\hline Percent & 4.80 & 4.75 & 10.00 & 1.25 \\
\hline \multicolumn{5}{|l|}{ Once or twice a year } \\
\hline Number & 2 & 17 & 0 & 1 \\
\hline Percent & 1.90 & 16.20 & 0.0 & 5.55 \\
\hline \multicolumn{5}{|l|}{ Over one year } \\
\hline Number & 4 & 1 & 1 & 1 \\
\hline Percent & 2.70 & 0.95 & 5.00 & 5.55 \\
\hline \multicolumn{5}{|l|}{ Never } \\
\hline Number & 3 & 5 & 7 & 7 \\
\hline Percent & 2.75 & 4.75 & 35.00 & 38.00 \\
\hline
\end{tabular}


Table 23. Frequency of non-delinquent's drinking compared with attitude toward drinking

\begin{tabular}{|c|c|c|c|c|}
\hline $\begin{array}{l}\text { Frequency } \\
\text { of drinking }\end{array}$ & $\begin{array}{l}\text { Nothing } \\
\text { wrong }\end{array}$ & $\begin{array}{l}\text { All right } \\
\text { if not } \\
\text { excessive }\end{array}$ & $\begin{array}{l}\text { Physically } \\
\text { harmful }\end{array}$ & $\begin{array}{l}\text { Morally } \\
\text { wrong }\end{array}$ \\
\hline \multicolumn{5}{|l|}{ Several times a week } \\
\hline Number & 7 & 8 & 0 & 0 \\
\hline Percent & 16.75 & 3.95 & 0.0 & 0.0 \\
\hline \multicolumn{5}{|l|}{ Once a week } \\
\hline Number & 8 & 14 & 1 & 0 \\
\hline Percent & 19.00 & 6.90 & 0.90 & 0.0 \\
\hline \multicolumn{5}{|l|}{$\begin{array}{l}\text { Two or three times } \\
\text { a month }\end{array}$} \\
\hline Number & 4 & 26 & 1 & 0 \\
\hline Percent & 9.50 & 12.90 & 0.90 & 0.0 \\
\hline \multicolumn{5}{|l|}{ Once a month } \\
\hline Number & 5 & 16 & 1 & 2 \\
\hline Percent & 11.90 & 7.90 & 0.90 & 1.92 \\
\hline \multicolumn{5}{|l|}{ Once every $2-5$ months } \\
\hline Number & 8 & 27 & 8 & 5 \\
\hline Percent & 19.00 & 13.80 & 7.25 & 4.80 \\
\hline \multicolumn{5}{|l|}{ Once or twice a year } \\
\hline Number & 3 & 33 & 1 & 7 \\
\hline Percent & 7.15 & 16.10 & 0.90 & 6.60 \\
\hline \multicolumn{5}{|l|}{ Over one year } \\
\hline Number & 1 & 18 & 2 & 2 \\
\hline Percent & 2.37 & 8.85 & 1.80 & 1.92 \\
\hline \multicolumn{5}{|l|}{ Never } \\
\hline Number & 6 & 62 & 97 & 88 \\
\hline Percent & 14.30 & 30.50 & 88.00 & 84.50 \\
\hline
\end{tabular}




\section{CHAPTER VI}

\section{SUMMARY AND CONCLUSIONS}

\section{Summary}

After a thorough review of available literature in the areas of delinquent and non-delinquent drinking behavior, a questionnaire was devised, pre-tested, and administered to delinquent students in the states of Idaho and Utah and to non-delinquent students in the state of Idaho.

The results were compiled, and a Chi square analysis was used to determine the difference in drinking behavior of delinquent and non-delinquent youth. Eight questions were then broken down for a more detailed examination of the relationship between the frequency of drinking and selected socio-economic and family influences. The percentages of the responses to these questions were computed with the delinquent and nondelinquent groups segregated by (1) sex, (2) age, (3) family income, (4) population of area lived in, (5) with whom the students lived, and (6) parents' drinking behavior.

The analyses of the results showed that delinquents began drinking sooner and more frequently than non-delinquents. In addition, the delinquents drank for different reasons than the non-delinquents. Delinquents drank without their parents' permission more often than the non-delinquents. A higher percentage of the non-delinquents claimed abstention in comparison with the delinquents.

This study also indicated that the older the delinquent 
and non-delinquent students were, the more frequently they drank. The frequency of drinking of both the delinquent and the non-delinquent students was related to the frequency of their parents' drinking. As the parents drank more frequently, the more frequently the delinquent and non-delinquent students drank.

\section{Conclusions}

The conclusions drawn from the responses of this sample of students were:

1. Delinquent students began drinking at an earlier age than non-delinquent students.

2. Delinquent students generally took theix fixst drink. with someone other than a parent or relative, while the majority of non-delinquents took their first drink with parents or relatives.

3. Delinquents drank more frequently than non-delinquents, and a higher percentage of delinquents drank than non-delinquents. 4. A higher percentage of delinquents drank hard liquor than non-delinquents. Non-delinquents drank beer most frequently.

5. A higher percentage of non-delinquents drank with their parents and received the alcohol they drank from them. The delinquents usually bought the alcohol they drank themselves or had a friend or older person buy it for them.

6. More delinquents "passed out" or could not remember activities while under the influence of alcohol than non-delinquents.

7. A higher percentage of delinquents had been arrested for drinking than non-delinquents. 
8. Both delinquent and non-delinquent students indicated a belief that drinking had some affect on the crimes committed by them.

9. The attitudes of the delinquents favored drinking. The non-delinquents ${ }^{\prime}$ attitudes were against drinking.

10. Sixteen was the age of heaviest drinking for both the delinquents and non-delinquents.

11. The delinquents at all ages drank more frequently than the non-delinquents.

12. Delinquent females drank as frequently as the delinquent males, while non-delinquent males drank more frequently than non-delinquent females.

13. Family income had no influence on the frequency of drinking of either the delinquents or the non-delinquents.

14. The size of the community had no influence on the drinking frequency of either the delinquent or the nondelinquent group.

15. With whom the students lived had no influence on frequency of drinking, although students who lived with their "father only" drank more frequently than those living with both parents or with their "mother only."

16. A relationship was indicated between parents' drinking behaviox and students' drinking behavior in both the delinquent and the non-delinquent groups.

17. The more frequently the delinquent and non-delinquent students drank, the more favorable were their attitudes toward drinking. 


\section{LITERA TURE CITED}

1. Blacker, Edward; Demone, Harold $W_{.}, J_{x}: s$ and Freeman, Howard E. Drinking Behavior of Delinquent Boys. Quarterly Journal of Studies on Alcohol 26(2):223-237. 1965 .

2. Block, Marvin A. Teen-age Drinking: Whose Responsibility? The International Student $60(2): 39.1963$.

3. Demone, Harold W., Jr. Drinking Attitudes and Practices of Male Adolescents. Dissertation Abstracts 27(10-A):3525-3526. 1967.

4. Downie, N. M. and Heath, R. W. Basic Statistical Methods. Harper and Row Publishers, New York. 225 p. 1959.

5. Jackson, Joan K. Chapter 13: Alcohol and Crime. Alcohol Education for Classroom and Community--A Source Book for Educators. McGraw-Hill Book Company, Inc., New York. 308 p. 1964.

6. Kliner, Lawrence, Chicago, Illinois, Mayor's Rehabilitation Committee Chairman. Chicago Daily News, August 8, 1961, as found in The International Student 60(2):31. 1963.

7. MacKay, James R.; Blacker, Edward; Demone, Harold W., Jr.; and Kelly, Francis J. Delinquency and Drinking (unpublished paper) as found in MacKay, James R.; Murray, Andrew E.; Hagerty, Thomas J.; and Collins, Lawrence J. Juvenile Delinquency and Drinking Behavior. Journal of Health and Human Behavior 4(4):276-279. 1963.

8. MacKay, James R.; Murray, Andrew E.; Hagerty, Thomas J.; and Collins, Lawrence J. Juvenile Delinquency and Drinking Behavior. Journal of Health and Human Behavior 4(4):276-282. 1963.

9. MacKay, James R.; Phillips, Derek L.; and Bryce, Forbes O. Drinking Behavior Among Teenagers: A Comparison of Institutionalized and Non-Institutionalized Youth. Journal of Health and Social Behavior 8(1):46-54. 1967.

10. Maddox, George L. Chapter 2: Adolescence and Alcohol. Alcohol Education for Classroom and Community--A Source Book for Educators. McGraw-Hill Book Company, Inc., New York. 308 p. 1964. 
11. Maddox, George L. Teenage Drinking and Planned Social Change. The Gateway 3(1). August, 1962. (Greensboro Council on Alcoholism), as found in Juvenile Delinquency and Drinking Behaviox. Journal of Health and Human Behavior 4(4):276. 1963 .

12. Maddox, George L. and McCali, Bevode. Drinking Among Teenagers: A Sociological Interpretation of Alcohol Use by High School Students. Monograph No. 4. Rutgers Center of Alcohol Studies, New Brunswick, New Jersey. 1964. (As found in Sociological Abstracts 13(5):669. 1965)

13. McCarthy, Raymond G. Alcohol and the Adolescent. Journal of School Health 30(3):99-106. 1960.

14. McCracken, J. E. Drinking and American Youth. The International Student $52(3): 67-68,80-84.1955$.

15. Mulford, Harold A. Drinking and Deviant Drinking, U. S. A., 1963. Quarterly Journal of Studies on Alcohol 25(4): 634-650. 1964. (As found in Nelson, Dale O. A Comparison of Drinking and Understanding of Alcohol and Alcoholism in Selected High Schools of Utah and the Utah State Industrial school. Unpublished study. Department of Health, Physical Education, and Recreation, Utah State University, Logan, Utah. 8 p. 1966.)

16. Nelson, Dale O. A Comparison of Drinking and Understanding of Alcohol and Alcoholism in Selected High Schools of Utah and the Utah State Industrial School. Unpublished study. Department of Health, Physical Education, and Recreation, Utah State University, Logan, Utah. 8 p. 1966.

17. Slater, A. D. A Study of the Use of Alcoholic Beverages Among High School Students in Utah. Quarterly Journal of Studies on Alcohol 13(1):78-86, 1952 .

18. Sower, Christopher. Teenage Drinking as Group Behavior: Implications for Research. Quarterly Journal of Studies on Alcohol 20(3):655-668. 1959 .

19. Wattenberg, William W. and Moir, John B. A Study of Teenagers Arrested for Drunkenness. Quarterly Journa I of Studies on Alcohol 17(3):426-436. 1956. 
APPENDIX 


\section{APPENDIX A}

\section{QUESTIONNA IRE}

\section{STUDY OF DRINKING HABITS OF SELECTED SECONDARY SCHOOL STUDENTS IN THE STATES OF IDAHO AND UTAH}

This questionnaire is part of a study to determine the drinking habits of teenagers. Since no one will be required to sign his name to this questionnaire, the person answering the questionnaire will remain anonymous. Therefore, please answer each of the following questions as accurately and as honestly as you possibly can.

1. At what age did you have your first high ball, can of beer, or alcohol cocktail? Never

2. Sex: M_F_ Race___ Age_ In what city or town have you resided most of your life? born there? Yes No Were you

3. What grade of school are you in now? 01212345678 Fr. Soph. Jr. Sr.

4. How do you feel your family ranks as far as yearly income is concerned? Under $\$ 3,000 \quad \$ 3,000-\$ 5,999 \quad \$ 6,000-\$ 10,000$ Above $\$ 10,000$ If you do not know your family's yearly income, what is the weekly (\$_) or monthly (\$_ ) income?

5. What type of area do you live in? Under 8,000 people $8,000-20,000$ Above 20,000

6. Whom do you live with at home? Both Parents Father only Mother only Nei ther

7. How often do your parents drink? Fa ther: Never 2 or 3 times a month Once or twice a $y x$. Once a week - Once every 2 to 5 mos. Once every month Several times a week Never

Mother: Once or twice a yr. Once every 2 to 5 mos. Once every month Every day 2 or 3 times a month Once a week Several times a week Every day

8. What was the first kind of alcoholic beverage you drank? Beer Wine Whiskey Other(specify) I don't drink

9. Did you have either of your parent's permission? Yes No

I don't drink 
10. Where did you have your fixst drink?

$\begin{array}{ll}\text {-Own home } & \text { Private club } \\ \text { - Home of a friend } & \text { High School Dance } \\ \text { - Restaurant, tavern, } & \text { - Relative's Home } \\ \text { or bar } & \text { - Automobile } \\ \text { Night club } & \text { I don't drink }\end{array}$

11. Whom were you with when you had your first drink? Parents Relative Boyfriend(s) -Girlfriend(s)

Alone
- Other (specify)
_-I don't drink
- Boys and girls

12. How did you obtain your first drink?

$\begin{array}{ll}\text { Bought it myself } & \text { Relative gave it to me } \\ \text { - Stole it } & \text { - Older person bought it } \\ \text { - Friend gave it to me -Other(specify) } \\ \text { - Parent gave it to me _- I don't drink }\end{array}$

13. Why did you take your first drink?

$\begin{array}{ll}\text { To feel grown up } & \text { - Other kids expected me to } \\ \text { - Just for "kicks" } & \text { - Family custom } \\ \text { - To "show off" } & \text { - To get up nerve } \\ \text { - Special occasion } & \text { - Curiosity } \\ \text { - } \text { - Other (specify) } \\ \text { - Bourage } & \text { - I never did drink }\end{array}$

14. How soon after your first drink did you drink again? Less than one week

One week

- Two weeks

Six months

-One year

Never

- I don't drink

15. How frequently do you drink alcoholic beverages on the average?

Several times a week
_ Two or 3 times a mon.
_ Once a week
_ Once a month

16. What type of alcoholic beverage do you drink most frequently? Beer

Vodka
Wine
Whiskey
Bourbon
Gin
Othex (specify)
I don't drink

17. With whom do you usually drink? Parents Relative
_ Boyfriend(s)
_ Girlfriend(s) Alone
Other (specify)
I don ${ }^{3} t$ drink
Boys and girls

18. Did you ever pass out while drinking? Yes No I don't dxink 
19. Were you ever unable to remember where you were or what you were doing while drinking? Yes No I don't drink

20. Have you ever been arrested for drinking? Yes_ No I don't dxink

21. Have you ever committed any crimes (other than traffic) while under the influence of alcohol? Yes__ No__. I don't dxink

22. If answer to question 21 is "yes," do you feel that you would have committed the crime had you not been under the influence of alcohol? Yes No

23. Where do you get the alcoholic beverages you drink? Parents or relatives Friends give it to me Other (specify) Older person gives it to me Buy it myself I don ${ }^{i}$ t drink

24. How do you consider drinking alcoholic beverages? (Mark only one answer)

Nothing wrong with it _ Physicaliy harmful
- All right if not in - Morally wrong
excess

25. How do you think drinking affects populasity? Favorably Unfavorably No effect

26. If you know any young people who drink, why do you think they drink?

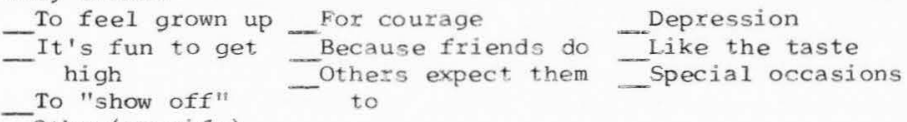
-_other (specify) 


\section{APPENDIX B}

\section{INSTRUCTIONS FOR ADMINISTERING QUESTIONNAIRE}

To the Administrator of the Questionnaire: Read word for word the following instructions to the students:

1. Do not put your names on the test; and upon receiving it, wait for further instructions.

2. (Pass out test.)

3. Read each question carefully and answer each question as honestly as possible. Do not ask any questions or make any comments while taking this test.

4. Mark one, and only one, answer on each question except question \#2. This is very important that you mark one, and only one, answer for each question.

5. This information will be confidential. There is no way of knowing which paper belongs to which student. The staff of this institution will not see individual papers. Therefore, you may be completely honest without fear of detection.

6. You may now read the instructions and start answering the questions. 
VIIA

Henry Dean Garrett

Candidate for the Degree of

Master of Science

Thesis: A Comparison of the Drinking Behavior of Delinquent versus Non-delinquent Juveniles in the States of Idaho and Utah.

Major Field: Health Education

Biographical Information:

Personal Data: Bron at Wellsville, Utah, January 10, 1940, son of Henry $W$. and Iola Bird Garrett; married Patsy May Pehrson, August 18, 1967; one child--Rosalie.

Education: Attended elementary school and junior high school in Wellsville, Utah; graduated from South Cache High School, Hyrum, Utah, in 1957; received Bachelors of Science degree from Utah State University, with a major in Audiology and Speech Pathology, in 1967; completed requirements for the Master of Science degree, specializing in Health Education, at Utah State University in 1969.

Professional Experience: 1968 to present, teacher at Brigham City West L. D. S. Seminary, Brigham City, Utah; 1967-68, teachez at Blackfoot L. D. S. Seminary, Blackfoot, Idaho. 